Landslides (2020) 17:2483-2501 DOI 10.1007/s10346-020-01462-y Received: 30 December 2019 Accepted: 10 June 2020 Published online: 22 July 2020 (c) The Author(s) 2020

\section{Jeffrey A. Coe \\ Bellwether sites for evaluating changes in landslide frequency and magnitude in cryospheric mountainous terrain: a call for systematic, long-term observations to decipher the impact of climate change}

\begin{abstract}
Permafrost and glaciers are being degraded by the warming effects of climate change. The impact that this degradation has on slope stability in mountainous terrain is the subject of ongoing research efforts. The relatively new availability of highresolution $(\leq 10 \mathrm{~m})$ imagery with worldwide coverage and short $(\leq$ 30 days) repeat acquisition times, as well as the emerging field of environmental seismology, presents opportunities for making remote, systematic observations of landslides in cryospheric mountainous terrain. I reviewed the literature and evaluated landslide activity in existing imagery to select five $\sim 5000-\mathrm{km}^{2}$ sites where long-term, systematic observations could take place. The five proposed sites are the northern and eastern flanks of the Northern Patagonia Ice Field, the Western European Alps, the eastern Karakoram Range in the Himalayan Mountains, the Southern Alps of New Zealand, and the Fairweather Range in Southeast Alaska. Systematic observations of landslide occurrence, triggers, size, and travel distance at these sites, especially if coupled with observations from in situ instrumental monitoring, could lead to a better understanding of changes in slope stability induced by climate change. The suggested sites are not meant to be absolute and unalterable. Rather, they are intended as a starting point and discussion starter for new work in this expanding landslide research frontier.
\end{abstract}

Keywords Climate change $\cdot$ Landslide $\cdot$ Rock avalanche $\cdot$ Rock fall - Debris flow - Frequency - Magnitude - Mobility · Hazard - Permafrost - Glacial retreat - Air temperature $\cdot$ Satellite imagery $\cdot$ Landsat $\cdot$ Sentinel $\cdot$ NISAR $\cdot$ Seismology $\cdot$ Monitoring

\section{Introduction}

Where should landslide researchers look for changes in slope stability induced by a warming climate? The most straightforward answer, which has been recognized since at least 1990 (e.g., Slaymaker 1990; Haeberli and Beniston 1998; Geertsema et al. 2006; Gruber and Haeberli 2007; Coe and Godt 2012; Huggel et al. 2012; Deline et al. 2015a; Gariano and Guzzetti 2016), is steep-cryospheric terrain in mountainous regions of the world because ice (either in permafrost or glaciers) in these areas is being degraded and reduced by warming temperatures (e.g., Paul et al. 2004; Harris et al. 2009; Huss and Hock 2015; Pastick et al. 2015; Kos et al. 2016; Zemp et al. 2019; Hock et al. 2020). An added benefit to these areas is that landslides are unlikely to be influenced by land use changes brought on by climate change. Land use changes by themselves can alter the frequency and magnitude of landslides (Sidle and Burt 2009; Petley 2010; Crozier 2010; Wasowski et al. 2010).

About $10 \%$ of the worldwide populace lives in mountainous regions that are susceptible to hazards resulting from a degrading cryosphere (Hock et al. 2020). The loss of ice in these regions impacts rock slopes in a variety of ways (e.g., Evans and Clague 1994; McColl 2012) including causing a reduction in cohesion and an increase in pore-water pressure in fractures in rocks (e.g., Gruber and Haeberli 2007) and debutressing (e.g., Deline et al. 2015a) and/or thermomechanically damaging (Grämiger et al. 2018) rock slopes when it occurs in the form of receding glaciers. Rock-slope failures in mountainous regions can trigger cascading hazard events, particularly when they enter lakes or fiords, where outburst floods, debris flows, and tsunamis can be generated (e.g., Evans and Delaney 2015; Haeberli et al. 2017; Higmann et al. 2018). The formation of new lakes and the expansion of fiords in areas of retreating glaciers increase the probability for cascading events that initiate as slope failure, and create hazards and risks in downslope areas where they may have not existed in the past (e.g., Haeberli et al. 2017). Risks to humans from these events increase as growing populations, tourism, transportation, and hydropower development expand into mountainous regions (Hock et al. 2020). A better understanding of changes in rockslope stability caused by the loss of ice could lead to improved delineation of hazard zones, improved models for forecasting landslides and associated cascading hazards, and identification of areas and populations with the greatest exposure to these hazards (Haeberli et al. 2017; Hock et al. 2020).

Worldwide, only a few studies have built systematic, long-term ( $\geq 20$ years) landslide catalogs that can be used to evaluate and compare the magnitude and frequency of landslide events through time in mountainous regions (Schlögel et al. 2011; Bessette-Kirton and Coe 2016; Coe et al. 2108; Hilbert et al. 2019), a problem that has been previously recognized by landslide researchers (e.g., Cox et al. 2015; Wood et al. 2015) and a recent Intergovernmental Panel on Climate Change (IPCC) special report (Hock et al. 2020, p. 175) that lamented a lack of studies to "systematically characterise and compare magnitude and extent of past impacts and future risk across high-mountain regions."

Remotely sensed imagery and seismic data are well suited to systematic monitoring in mountainous regions because they can provide observations of areas that are usually very difficult to access on the ground (e.g., Kääb 2002; Hibert et al. 2019). However, the lack of systematic landslide catalogs is due in large part to a lack of scale-appropriate remote monitoring tools, either (1) longterm, readily accessible imagery with high $(\leq 10 \mathrm{~m})$ and consistent resolution (to avoid mapping bias due to changing resolution) acquired at short (<30-day) acquisition intervals or (2) dense networks of permanent seismic monitoring stations (station spacing $<\sim 10 \mathrm{~km}\left(\right.$ ?)) in large (hundreds to thousands of $\mathrm{km}^{2}$ ) mountainous regions that are capable of routinely detecting a wide range of landslide sizes. Recent work by Dunning et al. (2015), 
who documented how a rock avalanche onto a glacier in New Zealand became masked by snow in remotely sensed imagery within 3 months after its occurrence, highlights the need for acquiring imagery at short time intervals.

The increasing number of Earth-observing satellites with high resolution, global coverage, and short acquisition periods, as well as the emerging field of environmental seismology (e.g., Kanamori and Given 1982; Faillettaz et al. 2008; Walter et al. 2008; and a special journal issue edited by Allstadt et al. 2019) applied to landslides (e.g., Berrocal et al. 1978; McSaveney and Downes 2002; Caplan-Auerbach and Huggel 2007; Helmstetter and Garambois 2010; Yamada et al. 2012; Allstadt 2013; Ekström and Stark 2013; Hibert et al. 2014; Allstadt et al. 2017), has the potential to revolutionize systematic remote monitoring of landslides. For example, in terms of new satellites, the joint U.S. National Aeronautics and Space Administration (NASA) and Indian Space Research Organisation (ISRO) Synthetic Aperture Radar Mission (NISAR) will launch in 2021 with the goal of repeat coverage of $70 \%$ Earth's ice-covered surfaces every 12 days and a displacement measuring capability of $100 \mathrm{~mm}$ or less (see https:// nisar.jpl.nasa.gov/). Additional examples include the European Space Agency (ESA)'s Sentinel-2 (https://sentinel.esa.int/web/sentinel/missions/sentinel-2) and Planet Labs (planet.com) satellites, both of which acquire moderate- to high-resolution (10-60 $\mathrm{m}$ for Sentinel-2 and $\leq 5 \mathrm{~m}$ for Planet Labs) optical imagery of the Earth's landmass surface at short time intervals $(<10$ days for Sentinel-2 and every day for Planet Labs). Given the abundance of these and other new imaging opportunities, as well as previously existing opportunities (e.g., Landsat [https://landsat.gsfc.nasa.gov/] and DigitalGlobe [https://www.digitalglobe.com]), focusing resources on a limited number of sites, rather than on the world as a whole, would seem to be the most productive way to make long-term systematic observations. This brings us back to the question of where to look for landslide changes.

This paper focuses on this question and proposes five bellwether sites for long-term slope stability monitoring using remote methods. The various definitions of bellwether include "an indicator or predictor of something," "one that takes the lead or initiative," and "an indicator of trends." These definitions all capture the essence of why the term is appropriate for selecting landslide monitoring sites for studies of the impacts from climate change. That is, the sites will potentially provide indications of changes that will eventually occur over broader mountainous areas. The types of landslides that could be monitored at these sites include rock falls, rockslides, rock avalanches, and debris flows. Below, I describe the site selection methodology and site characteristics and discuss possible approaches for making systematic observations at the sites. I have written this paper for the 5th World Landslide Forum (WLF), Theme 7, "Frontiers in landslide science and innovative practices." In addition to proposing bellwether sites, my intention in this paper is to provide the scientific justification for the work.

Methods

\section{Selection of bellwether sites}

To identify potential bellwether sites, I first searched the literature looking for mountainous areas with the likely presence of mountain permafrost, extensive glaciers that were receding or losing volume, past and future projected increases in air temperatures, and previous work and publications that documented landslide responses to warming temperatures and degrading permafrost or glaciers. After searching the literature, I spent several weeks looking through imagery in Google Earth and DigitalGlobe for mountain locations with a visual abundance of landslide deposits and/or sediment movement in the form of extensive glacial debris, recent glacial outburst flood deposits, or fresh landslide tracks on slopes. My philosophy in looking for recent landslide and sediment movement was that sites with existing moderate to high levels of activity would be most productive for gaining new insights into changes in landslide processes and hazards. By moderate to high levels of activity, I mean levels of activity that appear anomalous compared to their immediate surroundings, as well as compared to landslide activity in mountainous areas of other geographic regions. At the U.S. Geological Survey (USGS), we have had success using this approach to select in situ instrumental monitoring sites (e.g., the Chalk Cliffs debris-flow site in Colorado; Coe et al. 2008) and it appears that many other landslide researchers have used a similar approach to select their in situ monitoring sites (e.g., Hürlimann et al. 2019; Weber et al. 2019).

In addition to considering existing research and current levels of landslide activity, I also strove to identify potential bellwether sites with areas of about $5000 \mathrm{~km}^{2}$ and with a broad worldwide geographic distribution. I used $5000 \mathrm{~km}^{2}$ as target size because it was sufficiently large to characterize activity in a region, without being so large that it would be unmanageable. Additionally, that size had worked well for previous long-term systematic landslide observations in Alaska (Bessette-Kirton and Coe 2016; Coe et al. 2018).

After identifying potential sites, I used a tiered, semiquantitative selection procedure with four levels (Fig. 1) to select bellwether sites. The criteria that I used for potential sites to advance to each successively higher level are shown in Fig. 1. Criteria became more restrictive as progressing from level 1 to level 4, with level 4 being five bellwether sites that I selected. At level 1, I began with the seven continents and a goal of selecting one site from each continent. To advance to level 2, sites had to have extensive $(\geq 10)$ glaciers, mountain permafrost, and evidence for at least one landslide in the last 10 years. No sites from Antarctica or Africa met the level 2 criteria. To advance to level 3, sites needed to have met the previous criteria but also needed to have evidence for at least three landslides in the last 10 years. The criteria to advance to level 4 were more complicated and somewhat more subjective. Level 4 criteria included evidence for longterm records of landslides, existing landslide-monitoring infrastructure, and elevation and geographic position characteristics that were advantageous to achieve a broad range in bellwether site distribution characteristics. For example, the site that I selected in the Karakoram Range had a range in elevations unlike any of the other sites, which was advantageous in reaching level 4 .

For each bellwether site that I selected, I also compiled information on processes not related to climate change that could impact landslide magnitude and frequency. These processes included uplift related to plate tectonics or isostatic rebound, and earthquake occurrence. In an ideal situation, all landslide bellwether sites would not be impacted by any of these other processes, thus making the impact from warming temperatures easier to isolate and identify. Unfortunately, nearly all mountain ranges in 
cryospheric regions are impacted by at least one of these processes, and thus, they cannot be ignored.

\section{Results}

\section{Selected bellwether sites}

I have selected five bellwether sites (Fig. 2) that are geographically distributed in the northern and southern hemispheres and on five continents. All sites are in mid-latitude areas between 30 and $60^{\circ}$ (Fig. 2, Table 1), are partially covered by glaciers, and contain permafrost as modeled by Gruber (2012a, 2012b). All of the sites are at active, or formerly active, plate boundaries (Table 1) and are therefore susceptible to earthquake-triggered landslides, as well as climatically triggered landslides. Since 1901, mean air temperatures at all of the sites have increased by at least $0.5{ }^{\circ} \mathrm{C}$ (IPCC 2013; Fig. 3) and, using the medium-low Representative Concentration Pathway (RCP) 4.5 emissions scenario that stabilizes radiative forcing in the year 2100 (Thomson et al. 2011), future mean air temperatures at all of the bellwether sites are projected to increase by at least another $1{ }^{\circ} \mathrm{C}$ by 2065 (van Oldenborgh et al. 2013; Fig. 4). Projections of future changes in precipitation at the sites are uncertain, with estimated changes falling within a standard deviation of present-day variability (van Oldenburgh et al. 2013, pp. 1320-1321). For this reason, in this paper, I focus on changes in temperature, whose effects on the cryosphere will probably dominate over those induced by changes in precipitation (e.g., Alifu et al. 2016).

Below, I characterize each of the five bellwether sites in alphabetical order by country name. At the end of this section, I briefly describe other sites that were considered. I hope that readers of this article will have suggestions for additional sites. My lists of sites are not meant to be absolute and unalterable. Rather, they are simply intended as a starting point and discussion starter.

Eastern and northern flanks of the Northern Patagonia Ice Field, Chile In South America, an overall warming trend has been observed over the entire continent between 1901 and 2012 (Fig. 3). Since 1975, the largest magnitudes of $1{ }^{\circ} \mathrm{C}$ per decade have been observed in central Brazil (e.g., de Barros Soares et al. 2017). For the same period, in the Andes Mountains of southern Chile (i.e., Patagonia), observed warming has not been statistically significant (e.g., Carrasco et al. 2008; de Barros Soares et al. 2017), but valley glaciers on the flanks of the two major icefields (the Northern Patagonia Ice Field (NPI) and Southern Patagonia Ice Field (SPI)) have been rapidly receding and thinning (e.g., Davies and Glasser 2012; Willis et al. 2012). Combined, the NPI and SPI make up the largest extent of ice in the Southern Hemisphere outside of Antarctica, and their ongoing melting has contributed a

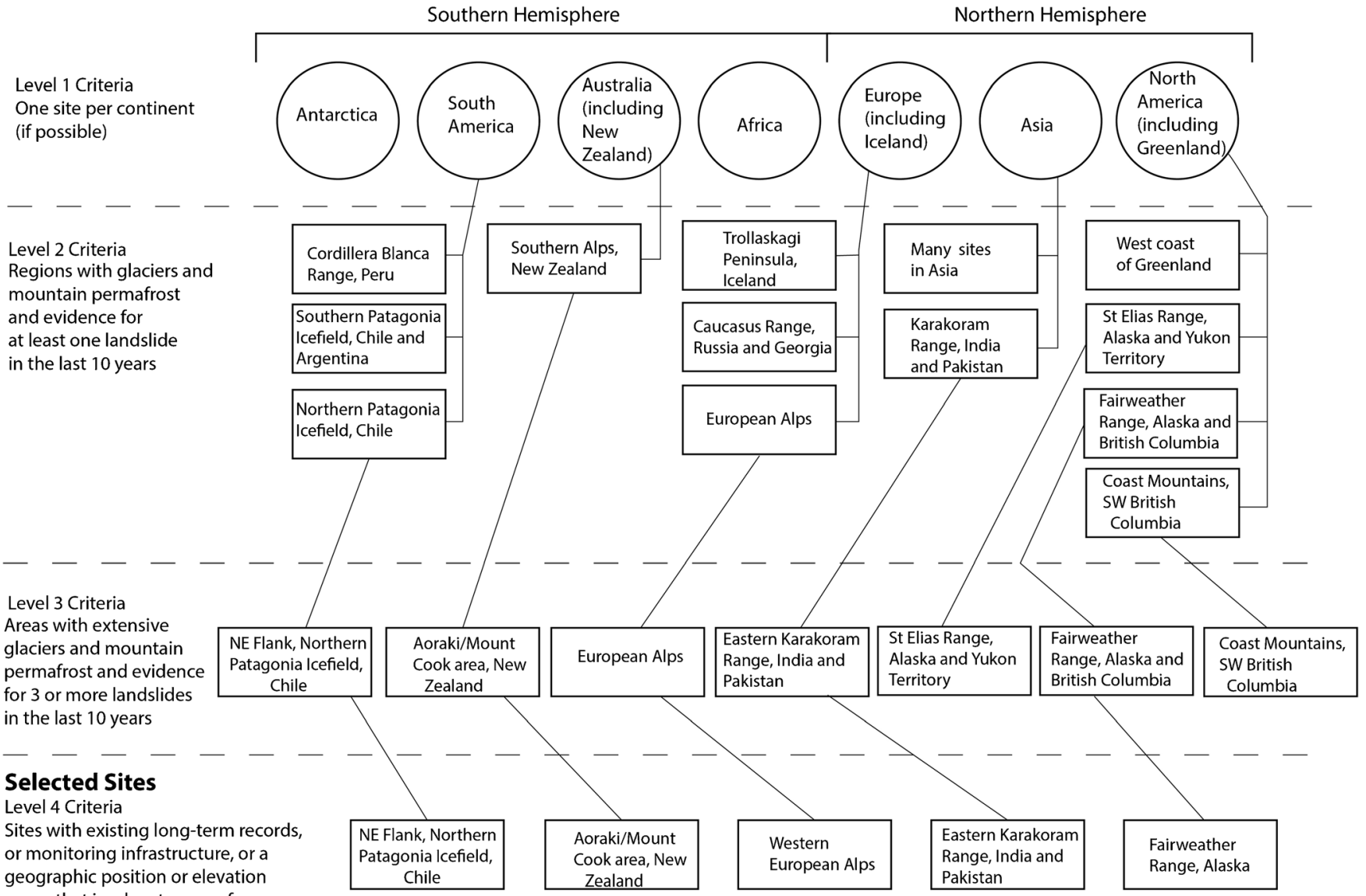

range that is advantageous for access

or distribution purposes

Fig. 1 Bellwether site selection tree 


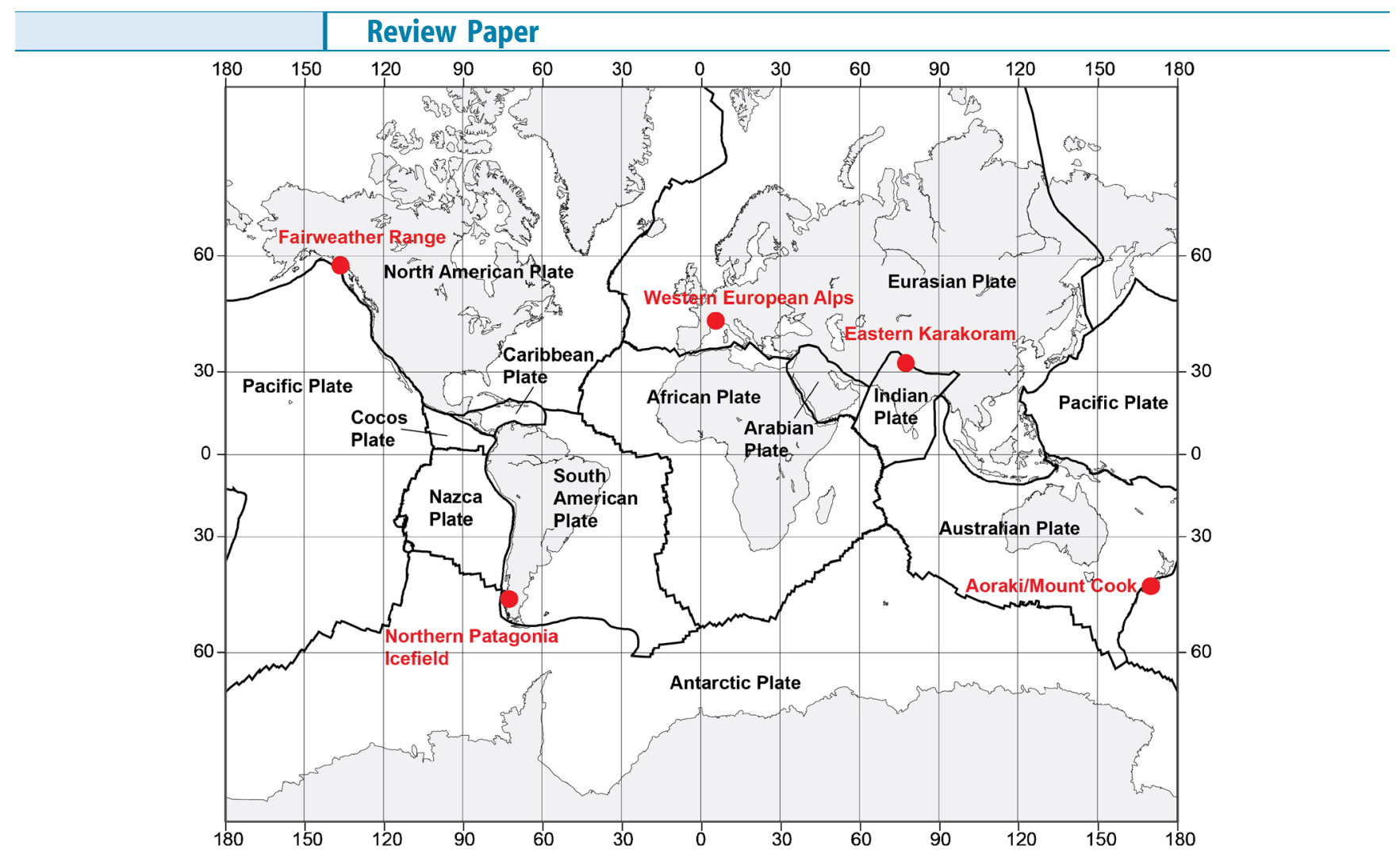

Fig. 2 Index map showing proposed bellwether sites in red font. Land masses are shaded light gray, tectonic plates are labeled, and boundaries are shown by black lines

disproportionate amount ( $9 \%)$ to sea-level rise compared to larger icefields in other parts of the world (Ringot et al. 2003). In agreement with these trends, Wilson et al. (2018) noted that within the Central and Southern Andes between 1986 and 2016, Patagonia had the highest number of glacial lakes and reported glacial-lake outburst floods (GLOFs) (e.g., Jacquet et al. 2017), as well as an increased rate of glacial-lake emergence since 2000. For the 20462065 time period, projections of air temperatures using the midlow-range RCP 4.5 emissions scenario indicate that average winter and summer temperatures will be 0.5 to $1.5{ }^{\circ} \mathrm{C}$ warmer than they were between 1986 and 2005 (Fig. 4; also see van Oldenborgh 2013, pp. 1346-1347, for higher-resolution details).

I selected a bellwether site along the eastern and northern flanks of the rapidly deglaciating NPI (Figs. 2 and 5) because glaciers are rapidly receding and thinning there (e.g., Davies and Glasser 2012; Willis et al. 2012) and because I observed about six large (areas $>0.2 \mathrm{~km}^{2}$ ), recent rock avalanches in glacier ablation areas in post-2010 satellite imagery (e.g., Fig. 5b). Some of these rock avalanches were previously identified as rock-fall deposits (Glasser et al. 2016). The bellwether site is about $220 \mathrm{~km}$ east of the triple junction of the Nazca, Antarctic, and South American tectonic plates (Fig. 2). This triple junction has subduction (compressive) and transform components, with the major LuquiñeOfqui right lateral fault zone running through the northwest part of the NPI (e.g., Georgieva et al. 2016). Georgieva et al. (2016) describe both strike-slip faults and thrust faults within the bellwether site and document exhumation rates of 0.1 to $0.9 \mathrm{~mm} /$ year. Dietrich et al. (2010) used campaign-style GPS between 2003 and 2006 to measure vertical crustal uplift rates (from combined isostatic and tectonic deformation) of about $16 \mathrm{~mm} /$ year south of the bellwether site. The western and central parts of the site (about $80 \%$ of the total area) are underlain by granites, granodiorites, and tonalites of the Cretaceous South Patagonia batholith (SERNAGEOMIN 2003). The eastern part of the site is underlain by Paleozoic metasediments (meta-sandstones and phyllites) and Jurassic monzodiorites, diorites, and granodiorites (SERNAGEOMIN 2003).

Chile is susceptible to landslides induced by climatic, volcanic, and seismic triggers (e.g., Francis et al. 1985; Hauser 2002; Nadim et al. 2006; Hermanns et al. 2012; Mather et al. 2014; Alfaro et al. 2017; Korup et al. 2019; Serey et al. 2019). However, few studies have been done within and near the bellwether site in southern Chile. Within the site, Fernandez and Coloma (2018) documented a $200,000-\mathrm{m}^{3}$ rockslide that mobilized as a rock avalanche and closed a road (for about 4 months) used by the tourist industry in the Exploradores Valley on the northern flank of the icefield (Fig. 5a). The rockslide occurred near the edge of a retreating glacier on October 27, 2017 (spring in the Southern Hemisphere), during an extended period (less than 1 month, but the exact length is unknown) of higher-than-normal air temperatures (Fernandez and Coloma 2018). About $200 \mathrm{~km}$ north of the bellwether site, landslides in Aysén Fjord triggered by a 2007 earthquake have been recently researched (e.g., Sepúlveda et al. 2010; Glüer 2011; Oppikofer et al. 2012). Also, more recently, Duhart et al. (2019) documented a 2017 rockslide and debris flow that destroyed part of the village of Santa Lucía. This rockslide began in altered volcanic rocks in an area of a retreating glacier at an altitude of about $1400 \mathrm{~m}$ above sea level, slid onto a glacier and ice-cored moraine, and then mobilized as a debris flow that traveled a total distance of $12 \mathrm{~km}$. Duhart et al. (2019) attribute the initiation of the landslide to a 2-week period when maximum daily temperatures exceeded $22{ }^{\circ} \mathrm{C}$, as well as $123 \mathrm{~mm}$ of rainfall in the 24 -h period 


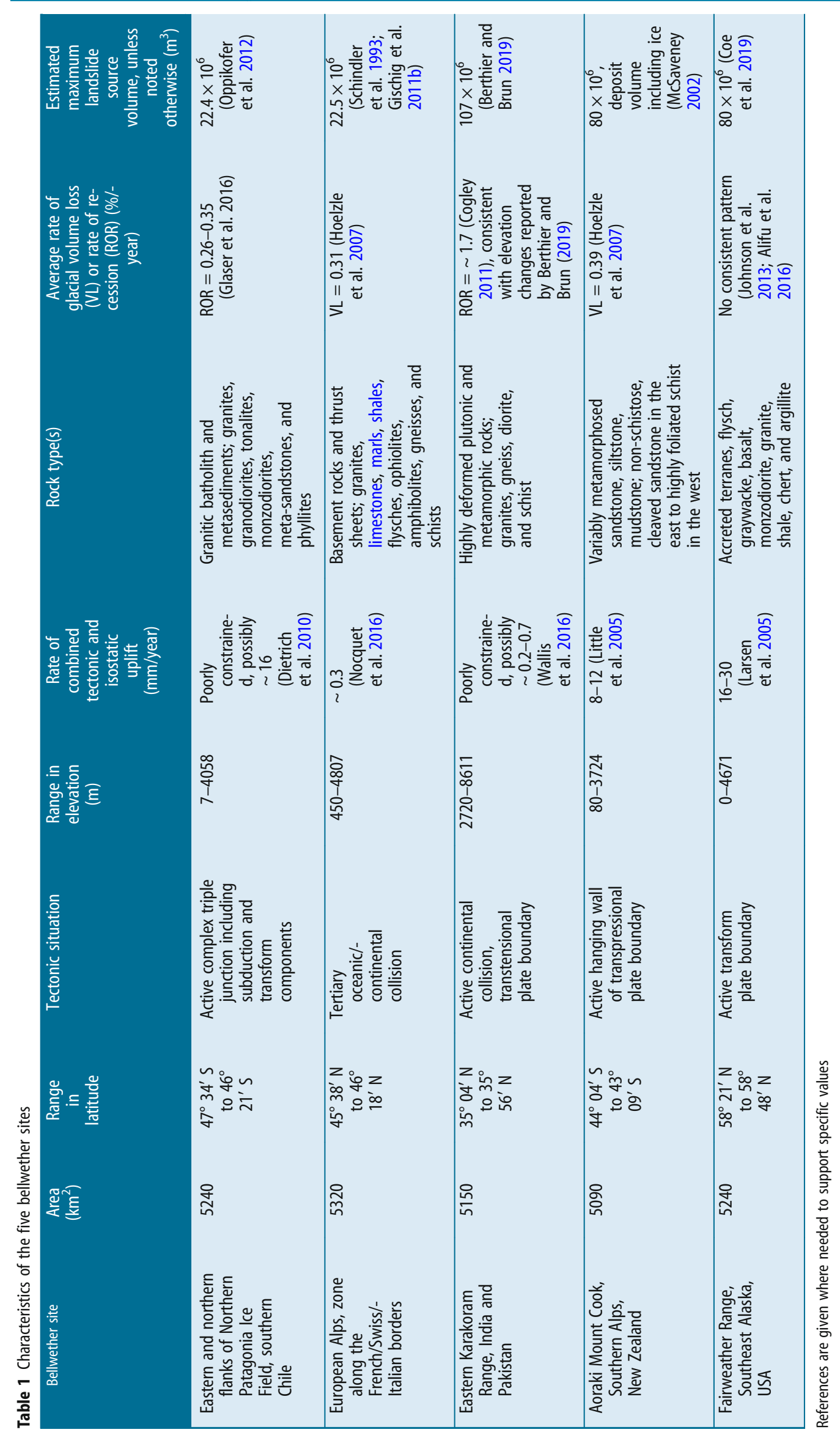


before to the rockslide. Work by Oppikofer et al. (2012) near Aysén Fjord suggests that landslides within the bellwether site likely have a maximum source area volume of about $22 \times 10^{6} \mathrm{~m}^{3}$.

\section{Western European Alps, France, Switzerland, Italy}

In the European Alps, one of the most densely populated mountainous regions in the world (Haeberli and Beniston 1998), an overall warming trend has been observed between 1901 and 2012, with temperature changes of about $1.8^{\circ} \mathrm{C}$ in the Southwestern Alps in the border region between France, Switzerland, and Italy (Fig. 3). Observations in Switzerland indicate that mean warming between 1975 and 2004 was $0.57{ }^{\circ} \mathrm{C}$ per decade, compared to $0.14{ }^{\circ} \mathrm{C}$ per decade between 1901 and 2000 (e.g., Rebetez and Reinhard 2008). During the late twentieth century, from 1985 to 1999, glaciers throughout the Alps decreased in size at a rate that was 7 times greater than the rate between 1850 and 1973 (Paul et al. 2004). Statistical modeling by Zemp et al. (2006) indicated that glaciers would be reduced another $80 \%$ (from their size in 2000) with a $3{ }^{\circ} \mathrm{C}$ increase in summer air temperature, even with a $10 \%$ increase in annual precipitation. Furthermore, Zemp et al. (2006) pointed out that this scenario could take place by the mid-to-late twenty-first century. More recent modeling that incorporated locally specific ice dynamics (Zekollari et al. 2019) confirmed these earlier results and indicated glacier losses of $79 \pm 9 \%$ by 2100 using the RCP 4.5 emissions scenario. For the 2046-2065 time period, projections of air temperatures using the RCP 4.5 emissions scenario indicate that average winter and summer air temperatures will be 1 to $3{ }^{\circ} \mathrm{C}$ warmer than they were between 1986 and 2005 (Fig. 4; also see van Oldenborgh 2013, pp. 1350-1351, for higherresolution details).

I selected a bellwether site in the Western European Alps (Figs. 2 and 6) because glaciers are rapidly shrinking there (e.g., Zemp et al. 2006; Salzmann et al. 2012) and permafrost is likely degrading (e.g., Harris et al. 2009) and because of an abundance of well-documented recent rock fall, rock avalanche, and debris flow activity that has been attributed to glacier withdrawal and/or degrading permafrost (e.g., Fig. 6b; Gruber et al. 2004; Chiarle et al. 2007; Deline et al. 2011; Fischer et al. 2006, 2012). The Western Alps formed during the Oligocene and Miocene epochs from convergence and collision of the Adriatic micro tectonic plate with the Eurasian Plate (e.g., Nocquet et al. 2016). This collision resulted in crustal thickening, development of extensive thrust sheets, and exhumation of basement rocks (e.g., Nocquet et al. 2016). Currently, no horizontal tectonic convergence occurs in the Western Alps (Fox et al. 2015; Nocquet et al. 2016), but Nocquet et al. (2016) estimate uplift rates of $\sim 0.25 \mathrm{~mm} /$ year, which they attribute to glacial erosion, isostatic rebound, and deep crustal dynamics. The bedrock geology underlying the bellwether site is complex and includes Carboniferous granites, Mesozoic marine limestones, marls and shales, and Cretaceous flysches, ophiolites, amphibolites, gneisses, and schists (e.g., Lacassin et al. 1990; Leloup et al. 2005; Bousquet et al. 2012).

Landslides linked to climate change in the Western Alps are the best documented in the world. Evidence for this statement comes from a multitude of papers on rock falls, rockslides, rock avalanches, and debris flows published in the twentieth and twenty-first centuries, which are too abundant to cite here. Instead, below, I try to mention the most relevant publications needed to provide support for selection of the bellwether site. Three of the best-known landslide study areas in the Alps, Mont Blanc, Monte Rosa, and the Matterhorn are located within the bellwether site (Fig. 6). At Mont Blanc, work on recent rock falls and rock avalanches has been particularly prominent (e.g., Ravanel et al. 2010; Ravanel and Deline 2011; Deline et al. 2011; Magnin et al. 2017). This work has shown that (1) mountain permafrost is highly sensitive to air temperatures; (2) the permafrost limit has been increasing in altitude, especially since the late 1990s; and (3) slope failures in rock occurred in response to air

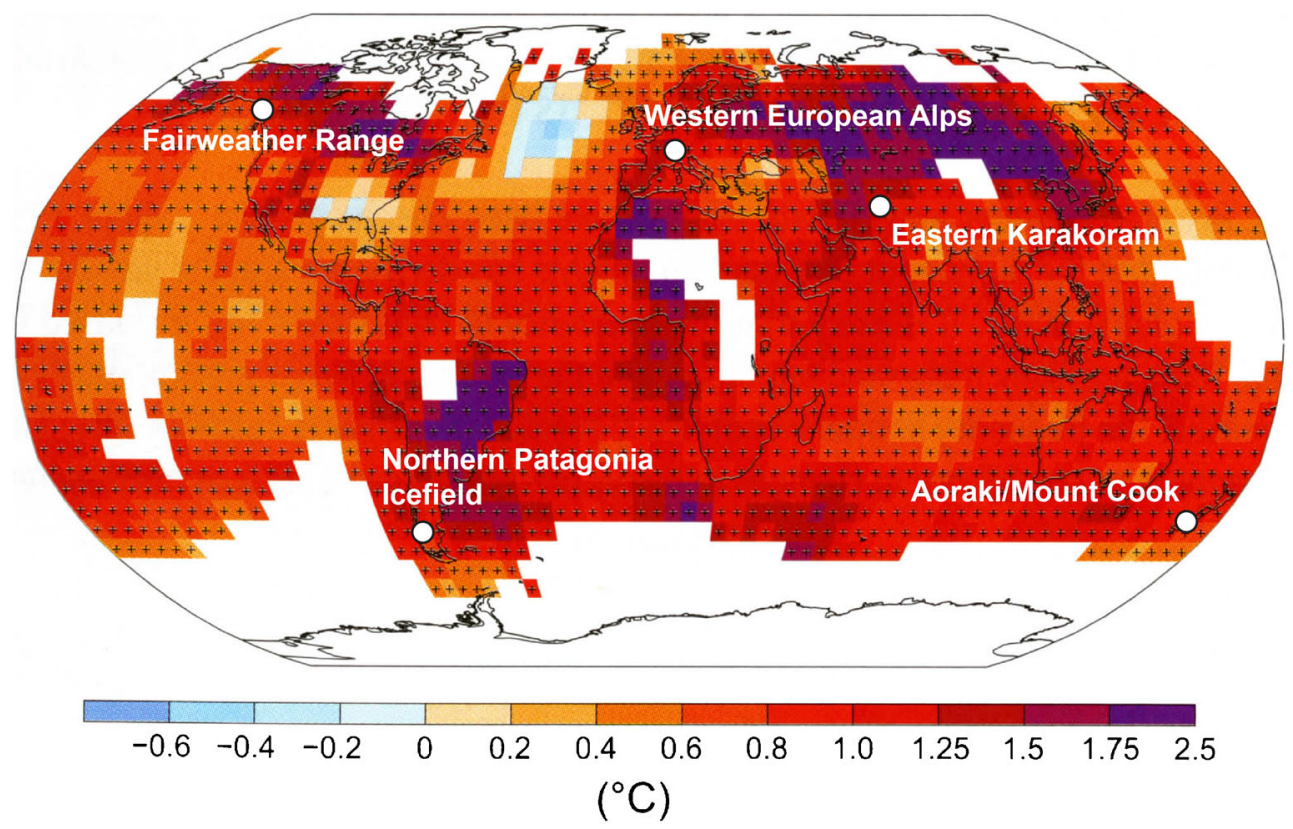

Fig. 3 Observed changes in mean surface air temperature from 1901 to 2012 (modified from IPCC 2013, p. 6). Bellwether sites are shown with white circle and are labeled. Observations in white grid cells were insufficient to estimate changes. Plus (+) signs show areas where observed trends are statistically significant 


\section{I}
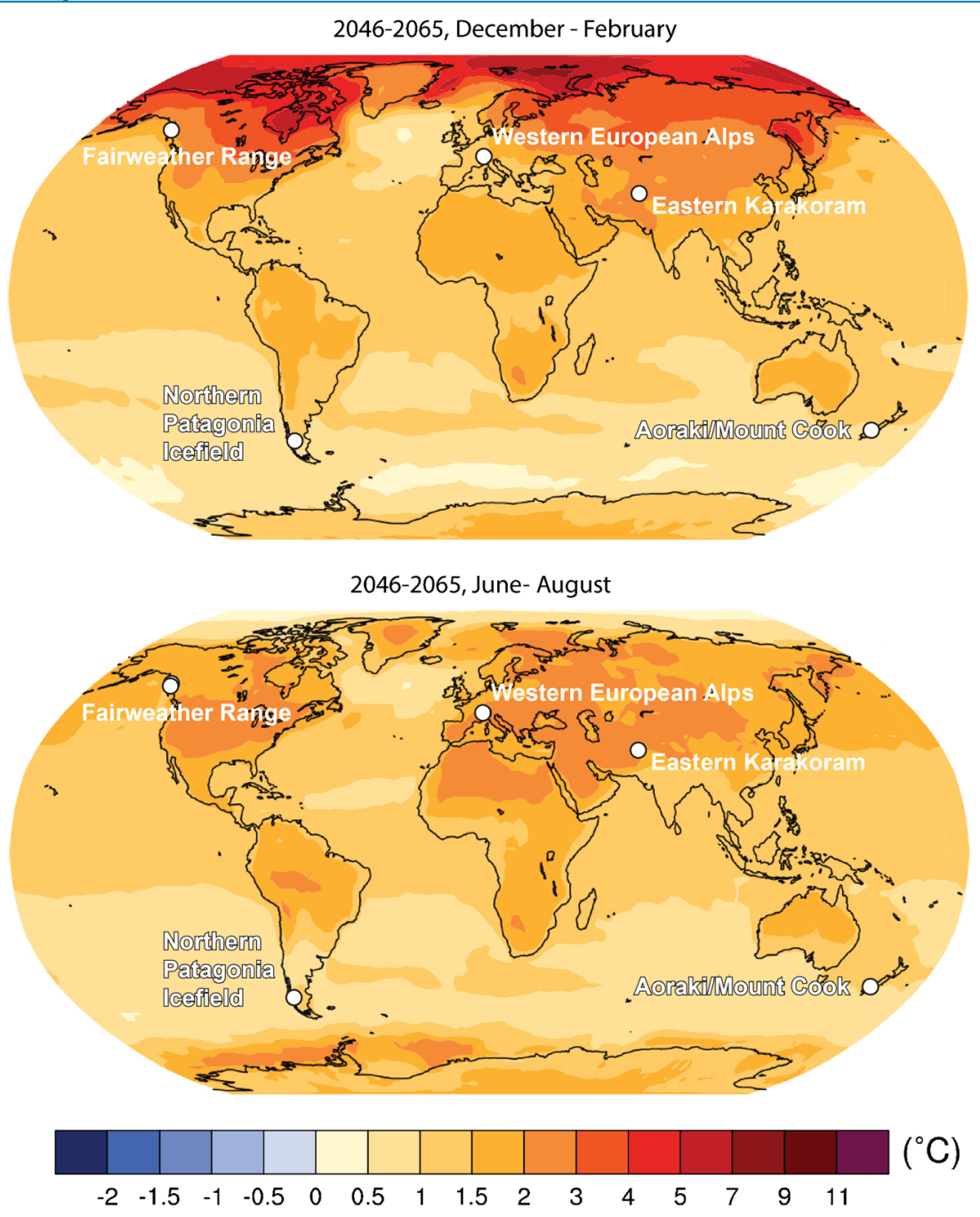

Fig. 4 Projected changes in median values (i.e., the 50th percentile from a distribution of multi-model simulation results) of mean air temperature for the period 20462065 compared to 1986-2005 using the RCP 4.5 emissions scenario (modified from van Oldenborgh et al. 2013). Simulation results from the Coupled Model Intercomparison Project 5 (CMIP5). Seasonal periods shown are December-February (top) and June-August (bottom)

temperature increases and permafrost degradation. At Monte Rosa, research on the east face (e.g., Haeberli et al. 2002; Fischer et al. 2006, 2013) has documented enhanced ice loss in the late twentieth and early twenty-first centuries and showed that recent rock falls, debris flows, and rock-ice avalanches have initiated from these areas. At the Matterhorn, in situ mountain permafrost monitoring campaigns began on the Swiss (e.g., Hasler et al. 2012; Weber et al. 2019) and Italian sides of the peak (e.g., Chiarle et al. 2015; Coviello et al. 2015) following the summer of 2003 extreme heat wave that triggered rock falls throughout the Alps (Gruber et al. 2004). Thus far, results from monitoring along a highly fractured ridgeline on the Swiss side have shown that for most of the year, fracture aperture was inversely related to temperature, except for a period during summer months when fracture aperture increased and shearing took place. This time period began with sustained melting and ended with the first freeze in the fall, suggesting the water reduced the strength in fractures containing perennial ice (Hasler et al. 2012; Weber et al. 2017). Another well-known landslide within the bellwether site is the 1991 Randa rockslide on the flank of a formerly glaciated valley that lacks permafrost (e.g., Gischig et al. 2011a, b). The studies at Randa suggest that landslides within the bellwether site have a maximum source area volume of about $22 \times 10^{6} \mathrm{~m}^{3}$.

\section{Eastern Karakoram Range, India and Pakistan}

In the Himalayan Mountains of Asia, an overall warming trend has been observed in the twentieth century, with temperature changes of 1.6 to $1.8^{\circ} \mathrm{C}$ in the Karakoram Range in Pakistan and India (Bhutiyani et al. 2007; Fig. 3). Recent observations from weather stations in northern Pakistan indicate that mean warming between 1986 and 2015 was $0.25^{\circ} \mathrm{C}$ per decade (Waqas and Athar 2019). Most glaciers in the Himalayas have receded during this time period (Kääb et al. 2012). In contrast, glaciers in the central Karakoram Range began expanding in the $1990 \mathrm{~s}$ (Hewitt 2005). Hewitt (2005) named this pattern the "Karakoram anomaly" and underscored the need for better monitoring of changing glaciers and climate in the area. More recent work indicates that the growth anomaly is still ongoing (e.g., Kääb et al. 2012; Farinotti et al. 2020; Paul 2020) and that 

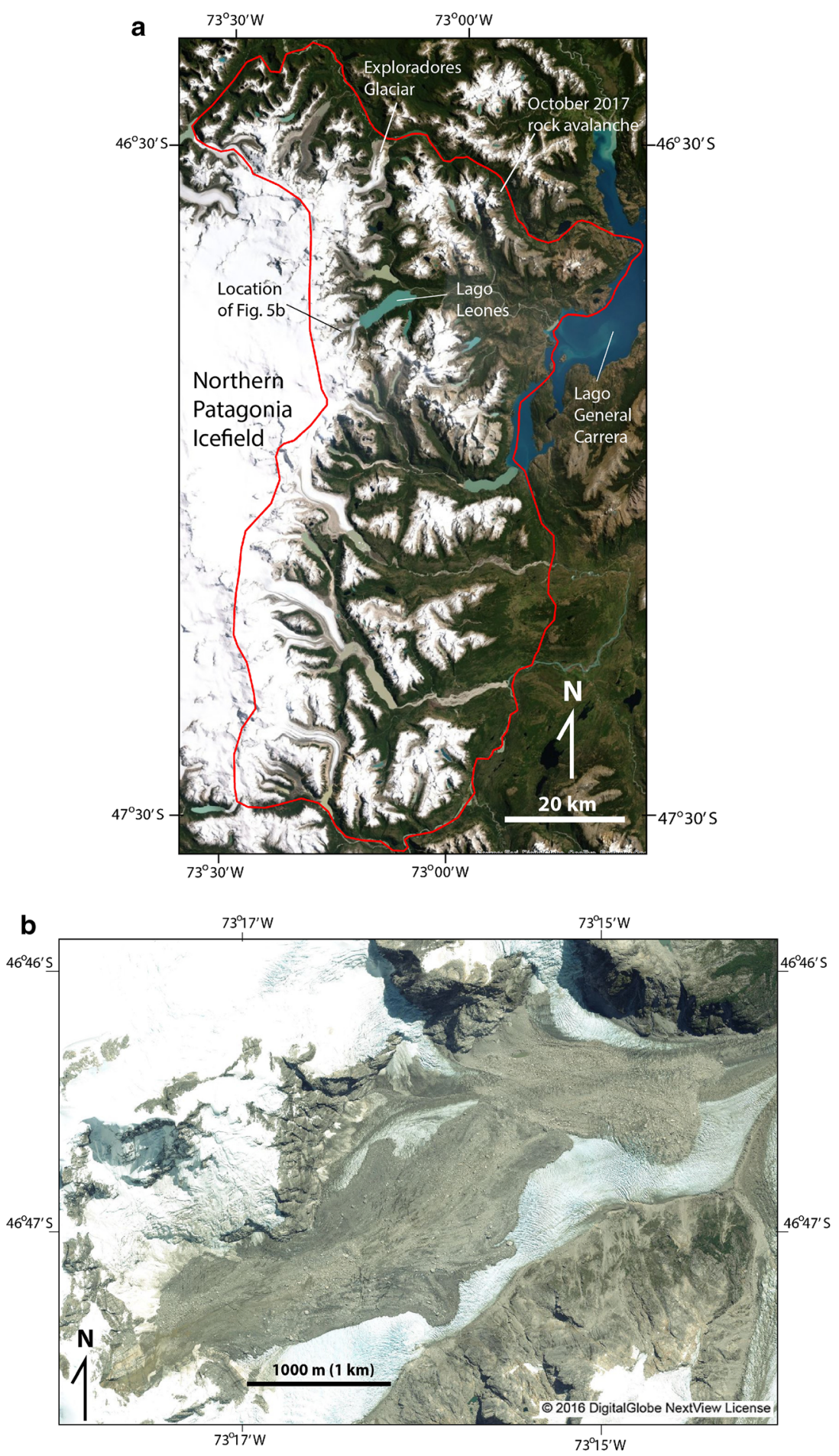

Fig. 5 a Bellwether site (outlined with a solid red line) along the eastern and northern flanks of the Northern Patagonia Ice Field, southern Chile. The October 2017 rock avalanche was described by Fernandez and Coloma (2018). Imagery from multiple sources available in ArcMap is shown. b Two rock avalanches on the Glaciar Leones about $5 \mathrm{~km}$ southwest of Lago Leones on the east flank of the Northern Patagonia Ice Field shown in a DigitalGlobe image acquired on January 29, 2019. Images in the DigitalGlobe catalog revealed that the rock avalanche on the right occurred first, between July 25 and October 4, 2014, and the rock avalanche on the left occurred second, between November 8, 2016, and January 12, 2017. The first avalanche was noted in an AGU blog posting by Pelto (2015) and by Glasser et al. (2016). The rock avalanches are herein named the Leones West rock avalanche (left) and Leones East rock avalanche (right)

it may be caused by summer cooling in the region caused by large-scale atmospheric circulation conditions (Forsythe et al. 2017). For the 2046-2065 time period, projections of air temperatures using the mid-low-range RCP 4.5 emissions scenario indicate that average winter and summer air temperatures will be 1.5 to $3{ }^{\circ} \mathrm{C}$ warmer than they were between 1986 and 2005 (Fig. 4; also see van Oldenborgh 2013, pp. 1366-1367, for higherresolution details). 


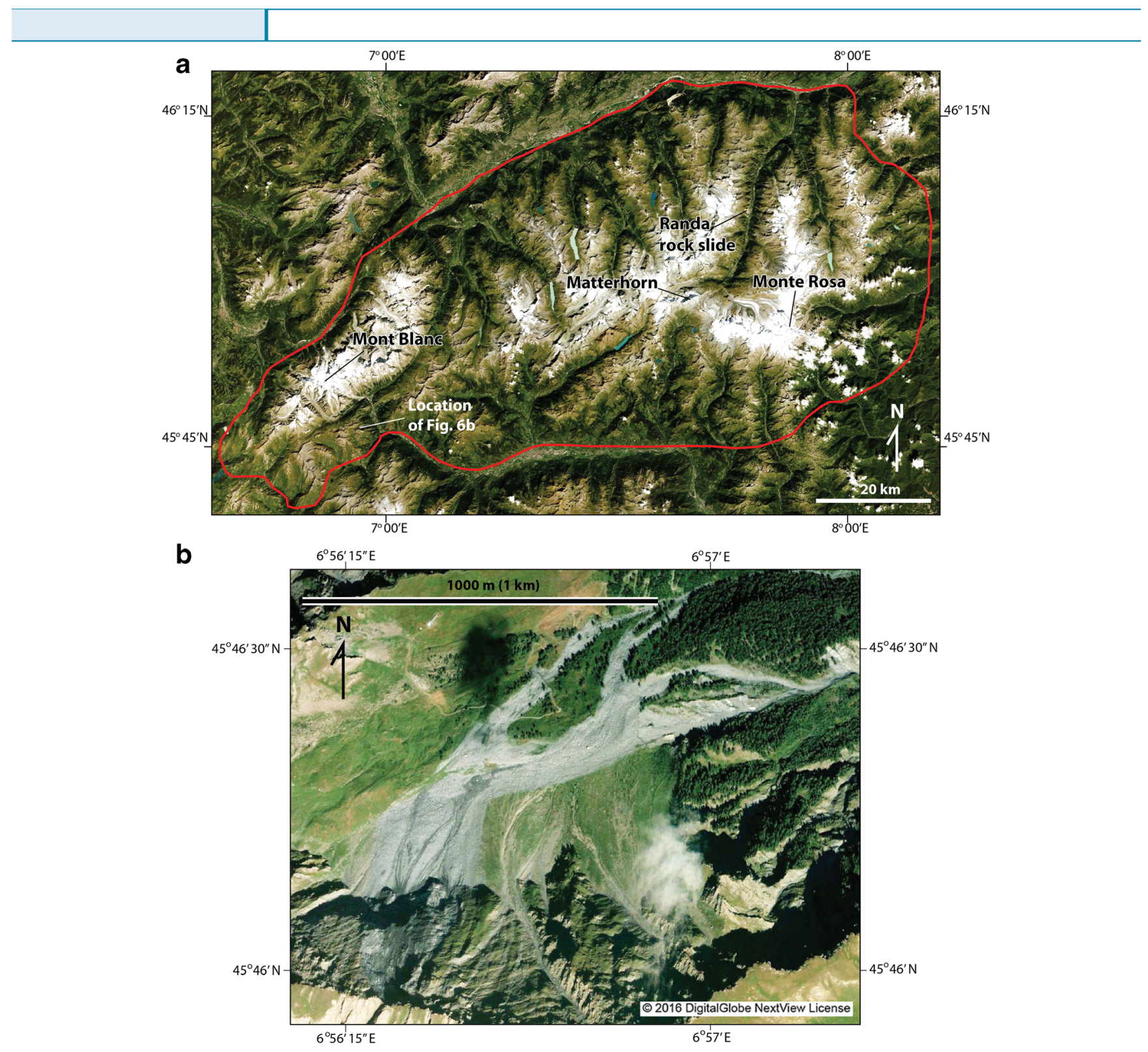

Fig. 6 a Bellwether site (outlined with a solid red line) in the Western European Alps of France, Switzerland, and Italy. Imagery from multiple sources available in ArcMap is shown. b December 24, 2008, $0.5 \mathrm{Mm}^{3}$ Mont Crammont rock avalanche in the Western European Alps (described by Deline et al. 2011) shown in a DigitalGlobe image from August 28, 2009. The source area was in the steep rock cliff in the lower left corner of the image

I selected a bellwether site in the eastern Karakoram Range along the eastern edge of the Karakoram anomaly, roughly centered on Siachen and Baltoro glaciers (Figs. 2 and 7), with lengths of $70 \mathrm{~km}$ and $67 \mathrm{~km}$, respectively. The site contains some of the highest peaks on Earth including $\mathrm{K}_{2}$ and Gasherbrum I, the 2nd and 11th highest at $8611 \mathrm{~m}$ and $8080 \mathrm{~m}$ above sea level, respectively. I selected this site because it provides an extreme elevation, endmember site where glaciers are currently not rapidly receding; monitoring in the area is sparse (Hewitt 2005); and rock avalanches have recently occurred (Fig. 7b; Petley 2012; Schneider et al. 2013; Bhutiyani and Mahto 2018; Berthier and Brun 2019).

The bellwether site is at the boundary between the Indian and Eurasian tectonic plates (Fig. 2). At this location, the plate boundary has compressive and transform components, with the major Karakoram right lateral strike-slip fault running through the central part of the bellwether site (e.g., Nakata 1989; Taylor and Yin 2009). The slip rate for the Karakoram fault, as well as vertical uplift in the Karakoram region, is poorly constrained (Taylor and Yin 2009; Wallis et al. 2016). Wallis et al. (2016) modeled average erosion exhumation rates of about $0.67+0.27 /-0.18 \mathrm{~mm} /$ year for the last 7.4 Ma and attributed variations in these rates to variations in vertical-rock uplift driven by tectonic-driven crustal thickening. The site is underlain by highly deformed plutonic and metamorphic rocks (Searle 1991; Fraser et al. 2001; Searle et al. 2010) including Tertiary Baltoro granites and $\mathrm{K}_{2}$ and Muztagh Tower gneisses, diorites, and schists.

The Karakoram Range is susceptible to landslides induced by climate and earthquake triggers (e.g., Khattak et al. 2010; Berthier and Brun 2019). Ken Hewitt of Wilfrid Laurier University has been studying rock avalanches and their impact on glaciers in the 

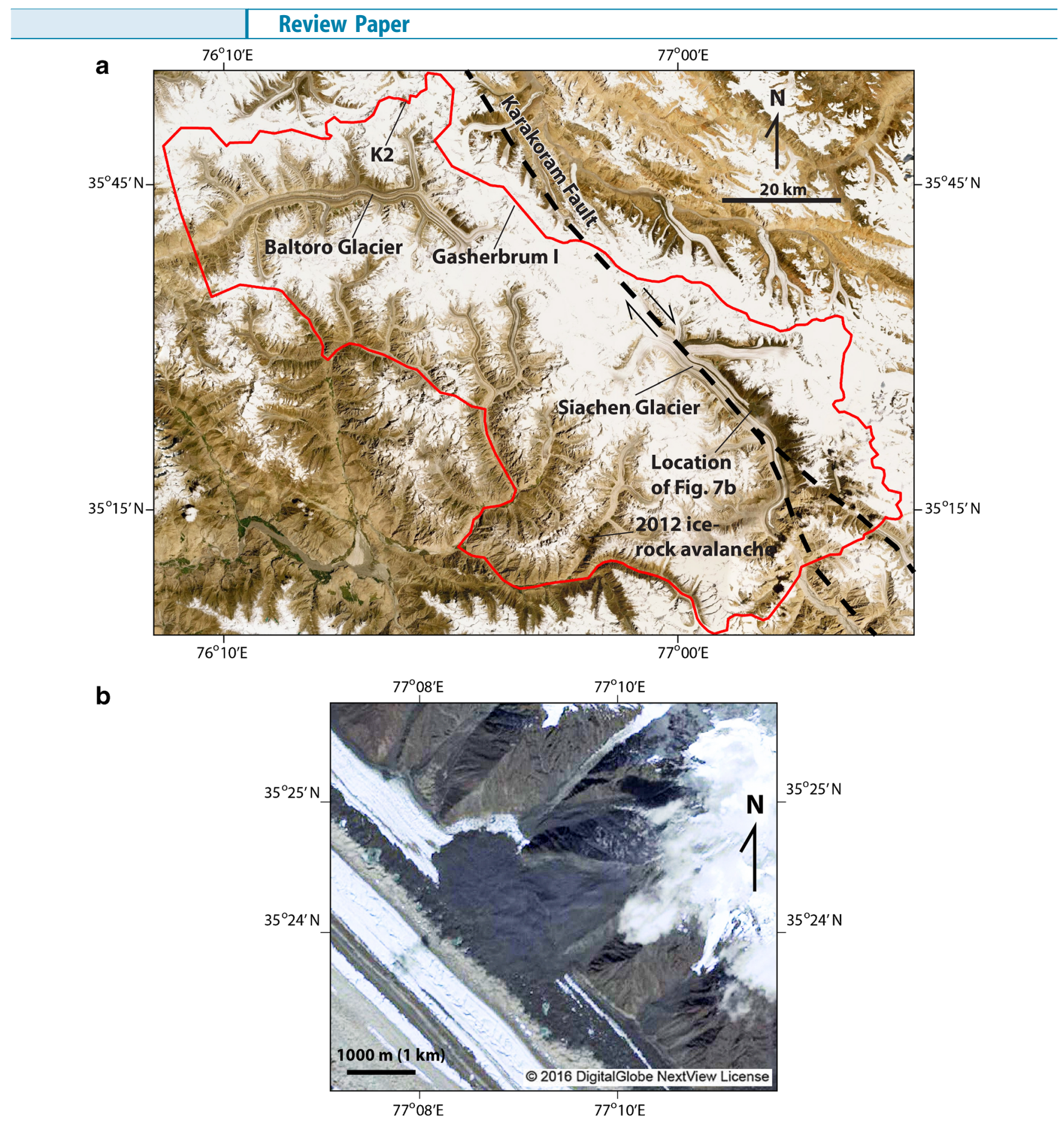

Fig. 7 a Bellwether site (outlined with a solid red line) in the Karakoram Range, Himalayan Mountains of India and Pakistan. Imagery from multiple sources available in ArcMap is shown. The approximate position of the Karakoram fault (from Searle and Phillips 2007) is shown by the thick dashed line. The 2012 ice-rock avalanche was described by Petley (2012). b September 2010 rock avalanche on the east side of the Siachen Glacier in the eastern Karakoram Range with an estimated volume of $~$ $109 \mathrm{Mm}^{3}$ (described by Berthier and Brun 2019). DigitalGlobe image acquired on October 9, 2010

central Karakoram (west of the bellwether site) for more than 30 years (e.g., Hewitt 1988, 2009) and has repeatedly stressed the need for additional research and monitoring of mass movements in the area. I chose a bellwether site mostly to the east of Hewitt's study area in the central Karakoram because it is generally at a higher elevation and has experienced ice loss between 2008 and 2010 and between 2014 and 2016 (Berthier and Brun 2019) and three large recent rock-avalanche events have been documented there: one in April 2012 (Petley 2012; Schneider et al. 2013), one in September 2010 on the Siachen Glacier (Fig. 7b; Ekström and Stark 2013; Berthier and Brun 2019), and another in April or May 2000 on the North Terong Glacier (Bhutiyani and Mahto 2018). The rock avalanche on April 7, 2012, was an ice-rock avalanche that killed 139 people in a Pakistani military camp on a debris fan (Petley 2012; Schnieder et al. 2013). The trigger for the event is unknown. The rock avalanche on the Siachen Glacier was a series of seven 
rock-slope failures from September 9 to 12 (Ekström and Stark 2013). The cumulative landslide source area volume for all of the failures was estimated at $107 \mathrm{Mm}^{3}$ by Berthier and Brun (2019). Additionally, Berthier and Brun (2019) point out that the cumulative $107 \mathrm{Mm}^{3}$ volume is larger than all rock avalanches in the worldwide catalog of rock avalanches onto glaciers (Table 9.1 in Deline et al. 2015b). The rock-avalanche deposit enhanced melting of the Siachen Glacier, contributing to a 6\% loss from 2010 to 2016 (Berthier and Brun 2019). The rock avalanche on the North Terong Glacier had an estimated volume of $7.6 \mathrm{Mm}^{3}$ and may have occurred during a period of anomalously warm temperatures from May 3 to May 4, 2000 (Bhutiyani and Mahto 2018)

\section{Aoraki/Mount Cook area, Southern Alps, New Zealand}

In New Zealand, observations indicate warming air temperatures in the twentieth and twenty-first centuries. An analysis of air temperature data from seven low-altitude stations on the North and South Islands found a 0.9 to $1{ }^{\circ} \mathrm{C}$ increase for the century between 1909 and 2009 (Mullan et al. 2010; Mullan 2012). A similar estimate from the IPCC (2013) indicates an overall warming trend between 1901 and 2012 of about $1.3{ }^{\circ} \mathrm{C}$ (Fig. 3). On the west side of the Southern Alps, Salinger et al. (1995) documented warming of $0.7^{\circ} \mathrm{C}$ between 1920 and 1990. For most of the twentieth and twenty-first centuries, glaciers in the Southern Alps have lost mass and retreated (e.g., Blair 1994; Chinn 1999, 2001; Hoelzle et al. 2007), with overall volume loss from 1850 to 2007 estimated at about $61 \%$ (Hoelzle et al. 2007). However, for an approximately two-decade-long period from the late 1970 s to the late 1990s, the volume of many large glaciers increased, while others, particularly debris-covered glaciers, continued to recede (Chinn 1999). Hoelzle et al. (2007) note that glaciers in the Southern Alps will probably be highly sensitive to future temperature increases because of their relatively low equilibrium-line altitudes (ELAs) and an increased likelihood of rain, as opposed to snow, in the future. For the 2046-2065 time period, projections of air temperatures using the mid-low-range RCP 4.5 emissions scenario indicate that average winter and summer air temperatures will be 0.5 to $1.5{ }^{\circ} \mathrm{C}$ warmer than they were between 1986 and 2005 (Fig. 4; also see van Oldenborgh 2013, pp. 1382-1383, for higher-resolution details).

I selected a bellwether site in the Southern Alps, centered on Aoraki/Mount Cook and encompassing the high-altitude, east and west sides of the north-south trending main divide (Figs. 2 and 8). I chose the site because glaciers are receding there (e.g., Hoelzle et al. 2007) and because historical slope failures in the area have been numerous, with indications that the frequency and size of events is increasing (McSaveney et al. 2014), although interpretations as to why this might be happening differ (McSaveney et al. 2014, 2015). The western edge of the bellwether site corresponds approximately with the oblique-reverse Alpine Fault (e.g., Cox and Barrell 2007; Little et al. 2005), which is the transpressive boundary between the Australian and Pacific tectonic plates (e.g., Walcott 1998; Fig. 2). Uplift occurs in the bellwether site on the east side of the fault. The estimated average fault slip rates for dextral and vertical components are $\sim 27 \mathrm{~mm} /$ year and $\sim 8-12 \mathrm{~mm} /$ year, respectively (Little et al. 2005). The site is underlain by variably metamorphosed and deformed Permian and Triassic sandstone with interbedded siltstone and mudstone (Cox and Barrell 2007). The metamorphic grade and internal deformation increase from east to west, with rocks along the eastern edge of the site being non-schistose cleaved sandstone and rocks on the western edge of the site at the Alpine Fault being highly foliated schist. On the west side of the bellwether site, west of the main divide, high rainfall rates result in abundant slope failures and erosion rates that are
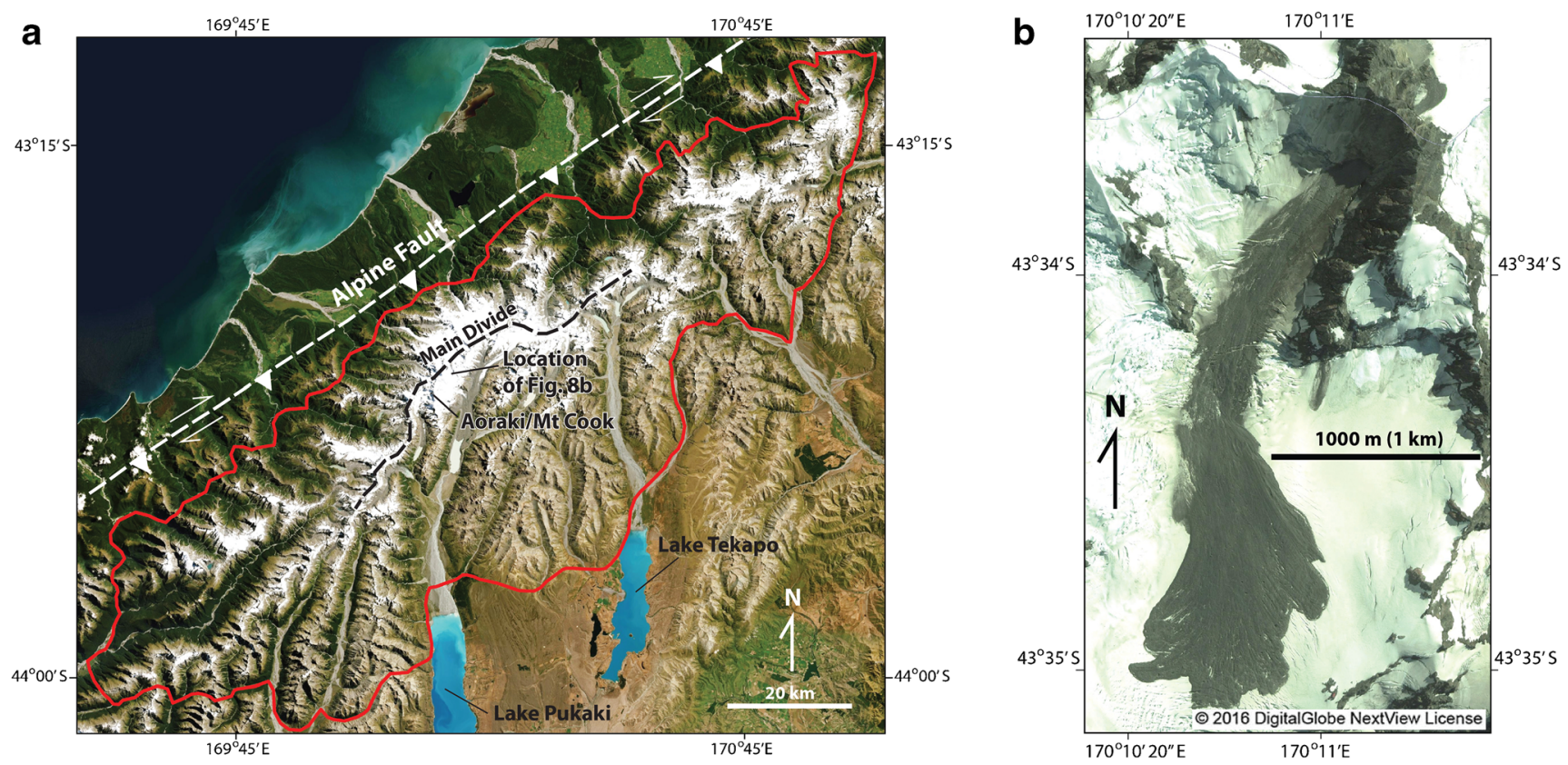

Fig. 8 a Bellwether site (outlined with a solid red line) in the Aoraki/Mt. Cook region of the Southern Alps, New Zealand. Imagery from multiple sources available in ArcMap is shown. Approximate position of the main divide shown with thick, black-dashed line. Approximate position of the Alpine Fault (from Cox and Barrell 2007) is shown with thick, white-dashed line, with teeth shown on upthrust side. b January 21, 2013, rock avalanche from a ridge connecting Mount Haast and Mount Dixon in the Southern Alps of New Zealand. Estimated volume is $\sim 2 \mathrm{Mm}^{3}$ (Dunning et al. 2015). DigitalGlobe image acquired on February 27, 2013 
roughly equal to the rate of uplift (Koons 1990; Hovius et al. 1997; Little et al. 2005).

Landslides have been extensively researched within the bellwether site (e.g., Whitehouse and Griffiths 1983; McSaveney 2002; Cox and Allen 2009; Allen et al. 2011; Cox et al. 2015; Cody et al. 2020), with a relatively long documented history of rock falls and rock avalanches, particularly from areas along and near the main divide (e.g., McSaveney 2002). In the early 1980s, Whitehouse and Griffiths (1983) used an inventory of 42 rock avalanches from a 1700 -year period of time to estimate a frequency for avalanches $>$ $1 \mathrm{Mm}^{3}$ at 1 per 94 years, with the largest in any century estimated at $56 \mathrm{Mm}^{3}$. Based in part on a temporal cluster of rock avalanches in the 1990s, McSaveney (2002) suggested a frequency for rock avalanches $>1 \mathrm{Mm}^{3}$ at 1 per 20-30 years. More recent work (McSaveney et al. 2014, 2015) suggests that the rate of rock avalanche occurrence since about 2004 is 2 per year. The reasons for this increase are unclear, with Allen et al. $(2009,2011)$ and Allen and Huggel (2013) tending to favor a mountain permafrost degradation explanation and McSaveney et al. $(2014,2015)$ favoring rock deformation from a global increase in seismic moment release and/or accumulating elastic strain since the last great earthquake on the Alpine Fault in $\sim 1717 \mathrm{AD}$. All researchers seem to agree that a fundamental problem is that many rock avalanches in the remote region are not recorded, and therefore, the existing record is too incomplete to definitively determine the impact of climate change on the distribution and frequency of recent landslides (e.g., Cox and Allen 2009; Allen et al. 2011; Cox et al. 2015). Work by McSaveney (2002) suggests that landslides within the bellwether site have a maximum total volume (including entrained ice) of about $80 \times 10^{6} \mathrm{~m}^{3}$.

\section{Fairweather Range, Southeast Alaska, USA}

In the USA, the greatest increases in air temperature and precipitation from climate change (e.g., van Oldenborgh et al. 2013; Walsh et al. 2014; Wuebbles et al. 2014; USGCRP 2018), and thus the most dramatic adverse impacts to slope stability, are expected in Alaska (Coe 2016). Mean air temperatures have increased in Alaska by at least $1.25^{\circ} \mathrm{C}$ since 1901 (Fig. 3). In 2014, Walsh et al. (2014) estimated an increase of $1.5{ }^{\circ} \mathrm{C}$ compared to the period between 1951 and 1980, with the most dramatic increases occurring during winter months. During a period from 2014 to 2016, mean air temperatures were the warmest on record (NOAA 2017; Walsh et al. 2017), and a cluster of exceptionally large rock avalanches occurred in the Fairweather Range in Glacier Bay National Park and Preserve (GBNPP) in Southeast Alaska (Coe et al. 2018), including the $70 \mathrm{Mm}^{3}$ Lamplugh rock avalanche (Bessette-Kirton et al. 2018).

Since 1995, glaciers in GBNPP have lost mass overall, but the mass balance is complicated locally, with some glaciers losing mass and others gaining mass (e.g., Johnson et al. 2013; Alifu et al. 2016). For the 2046-2065 time period, projections of air temperatures using the mid-low-range RCP 4.5 emissions scenario indicate that average temperatures in Southeast Alaska will be 1.5 to $3{ }^{\circ} \mathrm{C}$ warmer than they were between 1986 and 2005 (Fig. 4; also see van Oldenborgh 2013, pp. 1330-1331, for higher-resolution details).

I selected a bellwether site in the Fairweather Range in GBNPP (Figs. 2 and 9) because of its recent documented history of climatically induced rock avalanches (Fig. 9b; Bessette-Kirton and Coe
2016; Coe et al. 2018; Bessette-Kirton et al. 2018). The site is centered on a glaciated peninsula along the transform boundary of the Pacific and North American tectonic plates (Fig. 2). The plate boundary is marked by the strike-slip Fairweather Fault (Pflaker et al. 1978) which accommodates a large portion of the relative motion between the plates through a dextral slip of about $\sim 43 \mathrm{~mm}$ /year (Elliott et al. 2010). Elevations in the area range from sea level up to $4670 \mathrm{~m}$ above sea level at Mount Fairweather at the U.S.-Canadian border. Much of the study area is covered by ice, either in the form of valley glaciers or from the Brady icefield. In the last 250 years, the area has been undergoing rapid uplift (16 to $30 \mathrm{~mm}$ /year) caused primarily by viscoelastic rebound from postLittle Ice Age (LIA) deglaciation (Larsen et al. 2005). Glacier Bay proper (a fjord, Fig. 9a) is a result of post-LIA deglaciation (e.g., Connor et al. 2009).

Bedrock in GBNPP is exposed at mountain peaks, flanks, and ridge lines and in coastal zones. The bedrock geology is complex and consists of Paleozoic and Mesozoic accretionary terranes containing Tertiary sedimentary, intrusive, and volcanic rocks (Brew et al. 1978; Wilson et al. 2015). Bedrock units that surround Glacier Bay are Tertiary, Oligocene, and Eocene granitic rocks; the Cretaceous Chugach accretionary complex consisting of flysch, graywacke, and basalts; Cretaceous and Jurassic quartz monzodiorite; Cretaceous foliated granitic rocks; and Devonian to Ordovician shale, chert, and argillite (Wilson et al. 2015).

Glacier Bay National Park and Preserve has a history of both earthquake and climate-induced subaerial rockslides and rock avalanches (Miller 1960; Post 1967; Evans and Clague 1999; Geertsema 2012; Bessette-Kirton and Coe 2016; Bessette-Kirton et al. 2018; Coe et al. 2018; Dufresne et al. 2019). Because of the site's proximity adjacent to fjords, when these landslides rapidly enter the water, they can generate tsunamis with extraordinary destructive power. This destructive power was demonstrated by both the 1958 Lituya Bay earthquake-triggered rockslide (Miller 1960), which generated the largest tsunami runup height in history (524 m; Higmann et al. 2018). GBNPP's close proximity to the Fairweather Fault guarantees that large earthquakes will impact the area and trigger landslides in the future. However, since the M 7.8 earthquake that triggered the 1958 Lituya Bay rockslide and tsunami, at least 9o $M>4$ earthquakes have occurred within $100 \mathrm{~km}$ of GBNPP (the largest were two M 6.1 earthquakes: one in January 2000 and the other in July 2014). Coe et al. (2019) did not find any evidence that these earthquakes triggered rock-slope failures in GBNPP. Instead, all recent rockslides and rock avalanches in GBNPP have been associated with climatic triggers (i.e., most likely warm air temperatures; Coe et al. 2018). Between 1984 and 2016, at least 24 climatically induced rock avalanches occurred in GBNPP (Bessette-Kirton and Coe 2016) with a mean recurrence interval of 505 days (Coe et al. 2018). Available evidence indicates that these avalanches have increased in size and travel distance with time. Work by Coe et al. (2019) suggests that landslides within the bellwether site have a maximum source area volume of about $80 \times 10^{6} \mathrm{~m}^{3}$.

\section{Other sites considered as bellwether sites}

The five sites that I have selected are not the only sites where longterm observations could take place. These five sites are only meant as a starting point. Other sites that I considered as bellwether sites (Table 2) were the Coast Mountains of southwest British Columbia, Canada; the central west coast of Greenland; the Tröllaskagi Peninsula in northern Iceland; the Caucus mountain range at the border between Georgia and Russia; the St. Elias Mountains in 


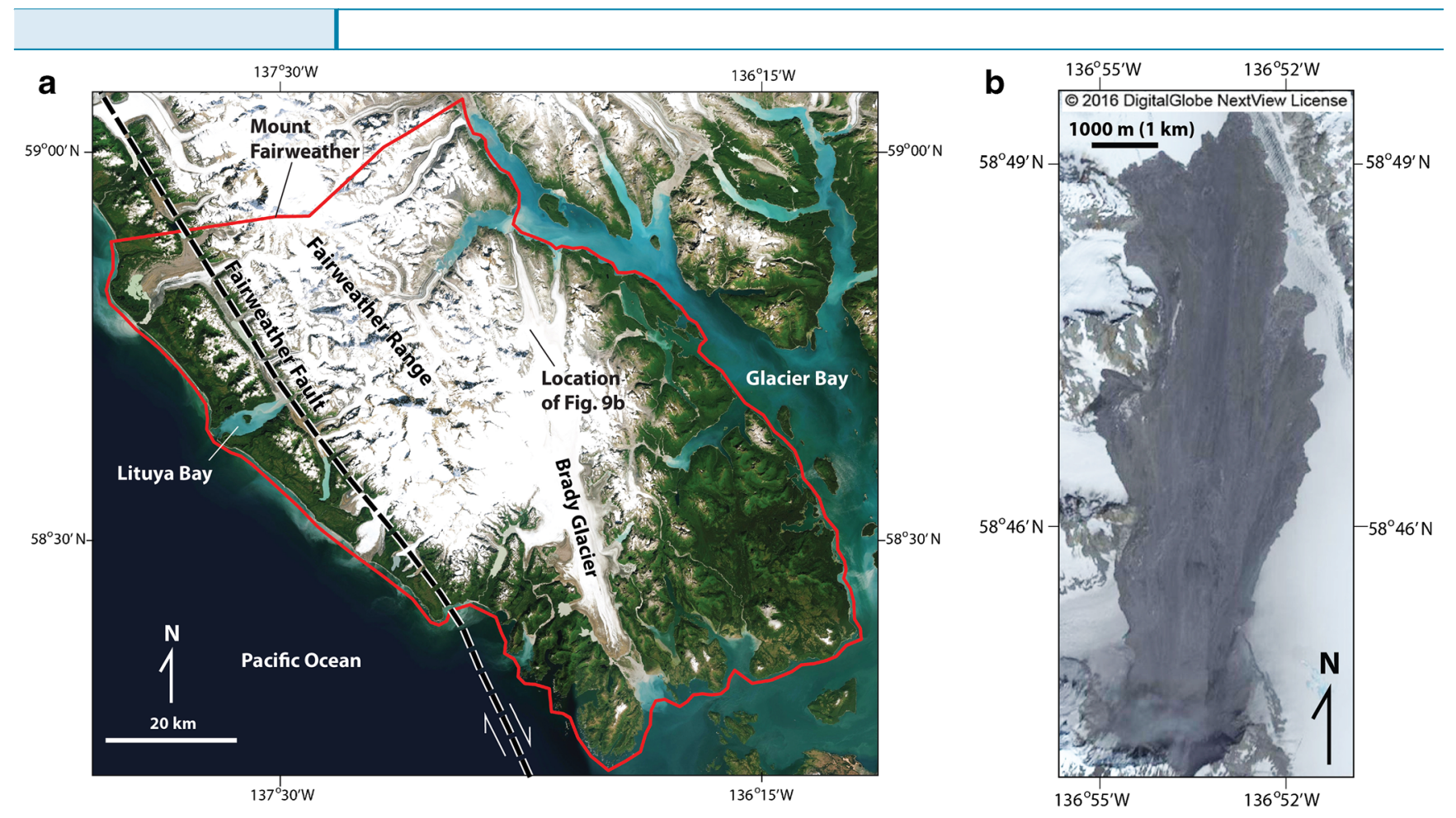

Fig. 9 a Bellwether site (outlined with a solid red line) in the Fairweather Range, Glacier Bay National Park and Preserve, Southeast Alaska, USA. Imagery from multiple sources available in ArcMap is shown. Approximate position of the Fairweather Fault (from Pflaker et al. 1978) is shown with thick, black-dashed line. b June 28, 2016, Lamplugh rock avalanche in the Fairweather Range. Measured volume from Bessette-Kirton et al. (2018) is $69.9 \mathrm{Mm}^{3}$ (also described by Bessette-Kirton (2017) and Dufresne et al. (2019)). DigitalGlobe image acquired on July 16, 2016

southern Alaska and the Yukon Territory; the Cordillera Blanca in Peru; and many sites in mountainous areas of Asia. Recent publications from each of these areas suggest that slope failures may be occurring in response to climate change (Table 2).

\section{Discussion}

\section{Possible approaches for making systematic observations}

As described above, landslide activity levels at the five bellwether sites are variable, with the Southern Alps, Fairweather Range, and the European Alps being most active; Northern Patagonia Ice Field being moderately active; and the Karakoram being the least active. Approaches for making long-term observations will need to account for differences in landslide sizes at the sites and ideally to establish minimum size detection thresholds early in the overall observation process.

A guide for how to proceed with long-term landslide observations could be taken from studies of glaciers. Glaciers are sensitive to climate change, and in most parts of the world, glaciers have receded since about 1985 (e.g., Paul et al. 2004). This period correlates well with the beginning of worldwide 30-m coverage by Landsat (the launch of Landsat 4 in 1982). As a first step, at each of the sites, landslides that are visible in Landsat imagery back to 1982 could be compiled. In Alaska, Landsat imagery provided a consistent medium that allowed Bessette-Kirton and Coe (2016) to systematically detect and map avalanches that covered areas larger than about 10 ha $\left(100,000 \mathrm{~m}^{2}, 0.1 \mathrm{~km}^{2}\right)$ from 1984 to 2016. This approach would also be viable in the Southern Alps, the Northern Patagonia Ice Field, and the Karakoram, but possibly not in the European Alps, where most recent documented landslides have generally been smaller than the other four sites. In the European Alps, higher resolution imagery and/or redundant systems such as a dense seismic network would probably be needed to capture the relatively small landslides that have recently been documented (e.g., Ravanel et al. 2010).

For seismic monitoring to be used routinely for detection of smalland medium-sized landslide events, several things would need to happen. First, denser networks of seismometers would need to be installed in remote, difficult to access places, and second, better automatic detection algorithms would need to be developed to better distinguish landslide signals from signals generated from other types of events, such as glacier movement (e.g., Caplan-Auerbach and Huggel 2007; Faillettaz et al. 2008; Walter et al. 2008). Of course, the installation and maintenance of a high density of seismometers in rugged mountainous regions is probably not economically feasible or practical in areas of $5000 \mathrm{~km}^{2}$. However, recent work has shown that existing regional seismic networks can be very useful for establishing the precise timing and evolution of large landslide events (e.g., Guthrie et al. 2012; Allstadt 2013; Ekström and Stark 2013; Iverson et al. 2015; Coe et al. 2016; Dufresne et al. 2019). This approach could be helpful at the bellwether sites, particularly during times with extensive cloud cover for long periods of time. But, at least for the foreseeable future, satellite imagery will probably be the primary tool that is routinely available for systematic landslide detection and mapping (for a wide range of landslide sizes) in the bellwether sites.

Landslide inventory mapping from repeat imagery with a consistent resolution and acquired over long ( $>30$-year) time frames is the essential data collection element at each bellwether site. The consistent resolution is essential to avoid biasing collected data toward more landslides being mapped from higher-resolution imagery. Inevitably, as the resolution of imagery continues to improve, the lower size threshold of landslides that can be detected will become smaller (for example, when changing from 30-m Landsat images to 5-m Planet Labs images). However, changing the resolution of imagery used for mapping 
Review Paper

Table 2 Other sites considered as bellwether sites, from level 2 of Fig. 1

\begin{tabular}{|c|c|c|}
\hline Location of potential bellwether site & $\begin{array}{l}\text { Latitude/longitude at the } \\
\text { approximate center of potential } \\
\text { site }\end{array}$ & $\begin{array}{l}\text { Recent publications describing slope failures in the region that may be } \\
\text { related to receding glaciers or degrading mountain permafrost }\end{array}$ \\
\hline $\begin{array}{l}\text { Coast Mountains, southwest British } \\
\text { Columbia, Canada }\end{array}$ & $123^{\circ} 00^{\prime} \mathrm{W}, 50^{\circ} 25^{\prime} \mathrm{N}$ & Guthrie et al. (2012); Cloutier et al. (2016); Friele et al. (2020) \\
\hline West coast of central Greenland & $53^{\circ} 04^{\prime} \mathrm{W}, 70^{\circ} 57^{\prime} \mathrm{N}$ & Bessette-Kirton et al. (2017); Svennevig et al. (2019) \\
\hline $\begin{array}{l}\text { Tröllaskagi Peninsula, north central } \\
\text { Iceland }\end{array}$ & $18^{\circ} 42^{\prime} \mathrm{W}, 65^{\circ} 42^{\prime} \mathrm{N}$ & Etzelmüller et al. (2007); Saemundsson et al. (2018) \\
\hline Caucasus Range, Russia and Georgia & $43^{\circ} 44^{\prime} \mathrm{E}, 42^{\circ} 46^{\prime} \mathrm{N}$ & Haeberli et al. (2004); Huggel et al. (2005) \\
\hline $\begin{array}{l}\text { St. Elias Mountains, southern Alaska, } \\
\text { USA, and Yukon Territory, Canada }\end{array}$ & $140^{\circ} 19^{\prime} \mathrm{W}, 60^{\circ} 04^{\prime} \mathrm{N}$ & $\begin{array}{l}\text { Huggel et al. (2008); Higman et al. (2018); Bessette-Kirton and Coe } \\
\text { (2020); Jacquemart and Loso (2019) }\end{array}$ \\
\hline Cordillera Blanca Range, Peru & $77^{\circ} 32^{\prime} \mathrm{W}, 9^{\circ} 10^{\prime} \mathrm{S}$ & Evans et al. (2009); Haeberli et al. (2017) \\
\hline $\begin{array}{l}\text { Southern Patagonia Ice Field, Chile } \\
\text { and Argentina }\end{array}$ & $73^{\circ} 18^{\prime} \mathrm{W}, 49^{\circ} 28^{\prime} \mathrm{S}$ & SERNAGEOMIN (2018) \\
\hline
\end{tabular}

Potential sites in Asia (shown in level 2 of Fig. 1) are too numerous to list here

should not occur in a haphazard manner. Rather, a consistent resolution should be used for as long as possible. Then, when the imagery used for mapping changes, distinct breaks should be noted in the record of each bellwether site so that the change can be acknowledged and accounted for when analyzing for changes in the frequency and magnitude in the time series of mapped landslides. At a minimum, data collected for each mapped landslide should include a date of occurrence or range in possible dates of occurrence, time of occurrence (if available), type of landslide trigger, landslide polygon, landslide area, slope direction (aspect) of source area, curvilinear travel distance from headscarp to toe, headscarp elevation, toe elevation, and a height/length calculation. Bessette-Kirton and Coe (2016) provide a possible template for items that should be recorded. Determining a specific type of trigger may not be possible, but at a minimum, there should be a binary answer (yes or no) as to whether an earthquake was involved, as well as measured values of air temperature and precipitation for antecedent time periods of 1 day, 2 days, 1 week, 1 month, 3 months, 6 months, and possibly, 12 months. Earthquake records from regional or local seismic networks will need to be searched for possible earthquakes at the time that landslides occurred. One possible search method is given in Coe et al. (2018). Volume estimates would also be helpful, but they are typically difficult to accurately measure. If accurate $( \pm 20 \%)$ volumes are not possible, they should not be reported.

Overall, research at the bellwether sites should focus on interconnected processes responsible for slope-stability changes in degrading cryospheric mountainous terrain. For establishing links between landslide characteristics (e.g., time of occurrence and size) and warming temperatures, as well as for gaining a better understanding of the physical processes controlling observed slope failures, long-term, in situ instrumental monitoring at high elevations in each bellwether will be required. An archetypical example of the type of in situ monitoring ideally needed is provided in a recent paper by Weber et al. (2019). However, at a minimum, in situ monitoring should consist of automated instrumentation to measure air temperature and precipitation.

A couple reasonable questions for landslide researchers to ask about this proposed work are who should do the work; how should long-term landslide observations at bellwether sites be funded, especially if commercial imagery needs to be purchased; and what group, if any, should be responsible for coordinating the efforts? In writing this paper, I have tried to provide a thought-provoking proposal for Theme 7 , "Frontiers in landslide science and innovative practices," of the 5th WLF in Kyoto, Japan (Sassa 2019a). I have tried to tailor the paper to fit well within Theme 7 by presenting a possible landslide research frontier, but with the full realization, those answers to the questions listed above still need to be determined. My intent with the paper was to provide the scientific basis and justification for bellwether sites, followed by a discussion of the proposal with other members of the international landslide community at the 5th WLF. My hope is that these discussions could lead to a clear path forward in terms of work distribution, coordination, and funding opportunities. To partly address these questions, in March 2020, I consulted with Duncan Quincey and Marta Chiarle, two of the officers of GAPHAZ (https://www.gaphaz.org/), an international scientific standing committee concerned with glacier and permafrost hazards in mountains, about the level of interest in the work, as well as possible collaborators and funding sources. After this consultation, my current opinion is that work at bellwether sites would best be done by landslide scientists and students with vested interest and expertise in regions where the proposed bellwether sites are located. The level of overall project coordination that will be needed, and what group (if any) should have that responsibility, remains to be determined and could be a topic of discussion at the 5th WLF. However, some possibilities include having the bellwether sites function in a manner similar to the way that U.S. National Science Foundation Critical Zone Observatories (CZOs) do for watersheds within the USA (https:// criticalzone.org/national/infrastructure/observatories-1national/), or perhaps the sites could become part of the network of GEO Geohazard Supersites (https://geo-gsnl.org/) that operate throughout the world. Additionally, the proposed, systematic, long-term approach to understanding interconnected processes responsible for slope-stability changes at bellwether sites fits well with the goals of the Mountain Research Initiative (https:// www.mountainresearchinitiative.org/) and their Group on Earth Observatories Global Network for Observations and Information in Mountain Environments (GEO GNOME) (https:// 
mountainresearchinitiative.org/activities/projects/geo-gnome) program.

Furthermore, in terms of funding, one possible source could be directly related to the 5 th WLF, a meeting with a focus on strengthening worldwide landslide collaboration and partnerships, particularly between the International Consortium on Landslides (Sassa 2019b), the United Nations University (OKI 2019), and the United Nations Educational, Scientific and Cultural Organization (UNESCO) (Nair-Bedouelle 2020). A study of climate change and its impact on slope stability in cryospheric mountainous regions throughout the world seems ideally suited for funding by such groups. Partnerships and collaborations between governments would also be beneficial to securing funding, establishing common mapping approaches, and integrating results.

\section{Conclusions}

The diversity of possible landslide responses to climate change (e.g., Gariano and Guzzetti 2016) places the landslide community in somewhat of a quandary as to the best way to proceed with research on the topic. In this paper, I have presented a proposal that calls on the international community of landslide researchers to use highresolution satellite imagery, as well as seismic networks where possible, to systematically monitor five $5000-\mathrm{km}^{2}$ cryospheric mountainous regions throughout the world. The five sites are the northern and eastern flanks of the Northern Patagonia Ice Field in southern Chile, the Western European Alps, the eastern Karakoram Range in the Himalayan Mountains, the Southern Alps of New Zealand, and the Fairweather Range in Southeast Alaska, USA. Some of these sites will be readily recognizable to landslide researchers who are already doing work related to climate change in these areas. I suggest that successful long-term observations at these "bellwether" sites will address a concern expressed in a recent Intergovernmental Panel on Climate Change special report (Hock et al. 2020) regarding a lack of studies to characterize and compare the magnitude of landslides in mountainous regions, and provide an indication of slope-stability changes at similar sites in other parts of the world.

\section{Acknowledgments}

I thank Christian Huggel, Stephen Slaughter, and Simon Allen for their constructive reviews of this paper. Conversations with Kate Allstadt were helpful while writing the first draft of the paper. Conversations with Marta Chiarle and Duncan Quincey were helpful during the revision of the paper. Suggestions by Jill McCarthy, Rex Baum, and Janet Slate improved the paper. I am grateful to Paul Duhart, Violchen Sepúlveda, Alejandro Alfaro, Javier Fernandez, Gonzolo Hermosilla, Leonardo Zuniga, and Stephen Slaughter for their expertise, guidance, and companionship on a recent trip to the proposed bellwether site in Patagonia. Any use of trade, firm, or product names is for descriptive purposes only and does not imply endorsement by the U.S. Government.

Open Access This article is licensed under a Creative Commons Attribution 4.0 International License, which permits use, sharing, adaptation, distribution and reproduction in any medium or format, as long as you give appropriate credit to the original author(s) and the source, provide a link to the Creative Commons licence, and indicate if changes were made. The images or other third party material in this article are included in the article's
Creative Commons licence, unless indicated otherwise in a credit line to the material. If material is not included in the article's Creative Commons licence and your intended use is not permitted by statutory regulation or exceeds the permitted use, you will need to obtain permission directly from the copyright holder. To view a copy of this licence, visit http://creativecommons.org/licenses/by/ 4.0/.

\section{References}

Alfaro, A, Falcón, MF, Arenas, M, Garrido, N, Espinoza, MC, Gajardo, A, Cervetto, M, Valdés, A, Aliaga, G, Opazo, E, Ramírez, P, Neira, H, Carrasco, R (2017) Geología para el Ordenamiento Territorial: área de Rancagua, región del Libertador General Bernardo O'Higgins. Servicio Nacional de Geología y Minería, Carta Geológica de Chile, Serie Geología Ambiental, No. 29, 109 p., 1 de 9 mapas escala 1:100.000, 1 CD con anexos, Santiago

Alifu H, Tateishi R, Nduati E, Maitiniyazi A (2016) Glacier changes in Glacier Bay, Alaska, during 2000-2012. Int J Remote Sens 37:4132-4147. https://doi.org/10.1080/ 01431161.2016.1207267

Allen SK, Gruber S, Owens IF (2009) Exploring steep bedrock permafrost and its relationship with recent slope failures in the Southern Alps of New Zealand. Permafrost and Periglacial Processes 20:345-356. https://doi.org/10.1002/ppp.658

Allen SK, Cox SC, Owens IF (2011) Rock avalanches and other landslides in the central Southern Alps of New Zealand. A regional study considering possible climate change impacts. Landslides 8:33-48. https://doi.org/10.1007/s10346-010-0222-z

Allen S, Huggel C (2013) Extremely warm temperatures as a potential cause of recent high mountain rockfall. Glob Planet Chang 107:59-69. https://doi.org/10.1016/ j.gloplacha.2013.04.007

Allstadt K (2013) Extracting source characteristics and dynamics of the August 2010 Mount Meager landslide from broad-band seismograms. J Geophys Res 118:1472-1490

Allstadt, KE, McVey, BG, Malone SD (2017) Seismogenic landslides, debris flows, and outburst floods in the Western United States and Canada from 1977 to 2017. U.S. Geological Survey data release. https://doi.org/10.5066/F7251H3W

Allstadt KE, Dietze M, Schopa A, Gimbert F, Turowski J., Walter F. (eds) (2019) From process to signal-advancing environmental seismology. Special issue, Earth Surface Dynamics. https://www.earth-surf-dynam.net/special_issue920.html

Berrocal J, Espinosa AF, Galdos J (1978) Seismological and geological aspects of the Mantaro landslide in Peru. Nature 275:532-536

Berthier E, Brun F (2019) Karakoram geodetic glacier mass balances between 2008 and 2016: persistence of the anomaly and influence of the large rock avalanche on Siachen Glacier. J Glaciol 65:494-507. https://doi.org/10.1017/jog.2019.32

Bessette-Kirton, EK, Coe, JA (2016) Inventory of rock avalanches in western Glacier Bay National Park and Preserve, Alaska, 1984-2016: a baseline data set for evaluating the impact of climate change on avalanche magnitude, mobility, and frequency. U.S. Geological Survey data release, https://doi.org/10.5066/F7C827F8

Bessette-Kirton, EK (2017) An analysis of landslide volume, structures, and kinematics from satellite imagery of the 2016 Lamplugh rock avalanche, Glacier Bay National Park and Preserve, Alaska. M.S. Thesis, Colorado School of Mines, 107 p. https:// hdl.handle.net/11124/171181

Bessette-Kirton, E, Allstadt, K, Pursley, J, Godt, J (2017) Preliminary analysis of satellite imagery and seismic observations of the Nuugaatsiaq landslide and tsunami, Greenland. https://www.usgs.gov/natural-hazards/landslide-hazards/science/preliminaryanalysis-satellite-imagery-and-seismic?qt-science_center_objects=0\#qtscience_center_objects

Bessette-Kirton EK, Coe JA, Zhou W (2018) Using stereo satellite imagery to account for ablation, entrainment, and compaction in volume calculations for rock avalanches on glaciers: application to the 2016 Lamplugh rock avalanche in Glacier Bay National Park, Alaska. J Geophys Res Earth Surf 123:622-641. https://doi.org/10.1002/2017JF004512

Bessette-Kirton, EK, Coe, JA (2020) A 36-Year Record of Rock Avalanches in the Saint Elias Mountains of Alaska, With Implications for Future Hazards. Frontiers in Earth Science 8:293. https://doi.org/10.3389/feart.2020.00293

Bhutiyani MR, Kale VS, Pawar NJ (2007) Long-term trends in maximum, minimum and mean annual air temperatures across the Northwestern Himalaya during the twentieth century. Clim Chang 85:159-177. https://doi.org/10.1007/s10584-006-9196-1

Bhutiyani MR, Mahto R (2018) Remote-sensing-based study of impact of a rock avalanche on North Terong Glacier in Karakorum Himalaya. Int J Remote Sens 39:1-16. https://doi.org/10.1080/01431161.2018.1480073 
Blair RW (1994) Moraine and valley wall collapse due to rapid deglaciation in Mount Cook National Park, New Zealand. Mt Res Dev 14:347-358

Bousquet, R, Schmid, SM, Zeilinger, G, Oberhänsli, R, Rosenberg, C, Molli, G, Robert, C, Wiederkehr, M, Rossi, P (2012) Tectonic framework of the Alps, CCGM/CGMW. https:// perso.univ-rennes1.fr/romain.bousquet/Alps/Maps/Alps_tectonic.html

Brew, DA, Johnson, BR, Grybeck, D, Griscom, A, Barnes, DF, Kimball, AL, Still, JC, Rataj UL (1978) Mineral resources of the Glacier Bay National Wilderness study area, Alaska. U.S. Geological Survey Open-File Report 78-494, U.S. Geological Survey, Reston, Virginia, 670 p., 6 sheets, scale 1:125,00. https://pubs.er.usgs.gov/publication/ofr78494

Carrasco JF, Osorio R, Casassa G (2008) Secular trend of the equilibrium-line altitude on the western side of the Southern Andes, derived from radiosonde and surface observations. J Glaciol 54:538-550. https://doi.org/10.3189/002214308785837002

Chiarle M, lannotti S, Mortara G, Deline P (2007) Recent debris flow occurrences associated with glaciers in the Alps. Glob Planet Chang 56:123-136. https://doi.org/ 10.1016/j.gloplacha.2006.07.003

Chiarle, M, Coviello, V, Arattano, M, Silvestri, P, Nigrelli, G (2015) High elevation rock falls and their climatic control: a case study in the Conca di Cervinia (NW Italian Alps). In: Lollino $\mathrm{G}$ et al. (eds) Engineering geology for society and territory - v. 1, Springer, pp. 439-442. doi: https://doi.org/10.1007/978-3-319-09300-0_84

Chinn TJ (1999) New Zealand glacier response to climate change of the past 2 decades. Glob Planet Chang 22:155-168

Chinn TJ (2001) Distribution of the glacial water resources of New Zealand. J Hydrol N Z 40:139-187

Cloutier C, Locat J, Geertsema M, Jakob M, Schnorbus M (2016) Potential impacts of climate change on landslides occurrence in Canada. https://doi.org/10.1201/ 9781315387789-5

Cody E, Draebing D, McColl S, Brideau M (2020) Geomorphology and geological controls on an active paraglacial rockslide in the New Zealand Southern Alps. Landslides 17:755-776. https://doi.org/10.1007/s10346-019-01316-2

Coe JA, Kinner DA, Godt JW (2008) Initiation conditions for debris flows generated by runoff at Chalk Cliffs, Central Colorado. Geomorphology 96:270-297. https://doi.org/ 10.1016/j.geomorph.2007.03.017

Coe JA, Godt JW (2012) Review of approaches for assessing the impact of climate change on landslide hazards. In: Eberhardt, E, Froese, C, Turner, AK, Leroueil, S (eds) Landslides and engineered slopes, protecting society through improved understanding. Proceedings of the 11th International Symposium on Landslides and 2nd North American Symposium on Landslides, Taylor \& Francis Group, London, pp. 371-377. https://www.researchgate.net publication/280683343_Review_of_approaches_for_assessing_the_impact_of_climate_ change_on_landslide_hazards

Coe JA (2016) Landslide hazards and climate change: a perspective from the United States. In: Ho KKS, Lacasse S, Picarelli L (eds) Slope safety preparedness for impact of climate change. CRC, Boca Raton, pp 479-523. https://doi.org/10.1201/9781315387789

Coe JA, Baum RL, Allstadt KE, Kochevar BF, Schmitt RG, Morgan ML, White JL, Stratton B, Hayashi TA, Kean JW (2016) Rock avalanche dynamics revealed by large-scale field mapping and seismic signals at a highly mobile avalanche in the West Salt Creek Valley, Western Colorado. Geosphere 12:607-631. https://doi.org/10.1130/GES01265.1

Coe JA, Bessette-Kirton EK, Geertsema M (2018) Increasing rock-avalanche size and mobility in Glacier Bay National Park and Preserve, Alaska detected from 1984-2016 Landsat imagery. Landslides 15:393-407. https://doi.org/10.1007/s10346-017-0879-7

Coe JA, Schmitt RG, Bessette-Kirton EK (2019) An initial assessment of areas where landslides could enter the West Arm of Glacier Bay, Alaska and implications for tsunami hazards. Alaska Park Science 18:26-37 https://www.nps.gov/articles/aps-18-1-4.htm

Cogley JG (2011) Present and future states of Himalaya and Karakoram glaciers. Annals of Glaciology 52:69-73

Connor C, Streveler G, Post A, Monteith D, Howell W (2009) The Neoglacial landscape and human history of Glacier Bay, Glacier Bay National Park and Preserve, Southeast Alaska, USA. Holocene 19:381-393. https://doi.org/10.1177/0959683608101389

Coviello, V., Chiarle, M., Arattano, M., Pogliotti, P., and Morra di Cell, M., (2015), Monitoring rock wall temperatures and microseismic activity for slope stability investigation at J.A. Carrel Hut, Matterhorn. In: Lollino, G et al. (eds) Engineering geology for society and territory - v. 1, doi: https://doi.org/10.1007/978-3-319-09300-0_57

Cox, SC, Barrell, DJA (2007) Geology of the Aoraki area. Institute of Geological and Nuclear Sciences 1:250,000 Geological Map Volume 15, pp. 1-80

Cox SC, Allen SK (2009) Vampire rock avalanches of January 2008 and 2003, Southern Alps, New Zealand. Landslides 6:161-166

Cox SC, McSaveney MJ, Spencer J, Allen SK, Ashraf S, Hancox GT, Sirguey P, Salichon J, Ferris BG (2015) Rock avalanche on 14 July 2014 from Hillary Ridge, Aoraki/Mount Cook, New Zealand. Landslides 12:395-402. https://doi.org/10.1007/s10346-015-0556-7

Crozier MJ (2010) Deciphering the effect of climate change on landslide activity: a review. Geomorphology 124:260-267
Davies BJ, Glasser NF (2012) Accelerating shrinkage of Patagonian glaciers from the Little Ice Age ( AD 1870) to the present day. J Glaciol 58:1063-1084

de Barros Soares D, Lee H, Loikith PC, Barkhordarian A, Mechoso CR (2017) Can significant trends be detected in surface air temperature and precipitation over South America in recent decades? Int J Climatol 37:1483-1493. https://doi.org/10.1002/joc.4792

Deline P, Alberto W, Broccolato M, Hungr 0, Noetzli J, Ravanel L, Tamburini A (2011) The December 2008 Crammont rock avalanche, Mont Blanc massif area, Italy. Nat Hazards Earth Syst Sci 11:1-12. https://doi.org/10.5194/nhess-11-3307-2011

Deline P, Gruber S, Delaloye R, Fischer L, Geertsema M, Giardino M, Hasler A, Kirkbride M, Krautblatter M, Magnin F, McColl S, Ravanel L, Schoeneich P (2015a) Chapter 15, ice loss and slope stability in high-mountain regions. In: Haeberli W, Whiteman C, Shroder JF Jr (eds) Snow and ice-related hazards, risks, and disasters. Academic, Amsterdam, pp 521-561. https://doi.org/10.1016/B978-0-12-394849-6.00015-9

Deline P, Hewitt K, Reznichenko N, Shugar, D. (2015b). Rock avalanches onto glaciers. In: Davies T, Shroder JF (eds) Landslide hazards, risks, and disasters. Amsterdam: Elsevier, Inc, pp 263-270. https://doi.org/10.1016/B978-0-12-396452-6.00009-4

Dietrich R, Ivins ER, Casassa G, Lange H, Wendt J, Fritsche M (2010) Rapid crustal uplift in Patagonia due to enhanced ice loss. Earth Planet Sci Lett 289:22-29. https://doi.org/ 10.1016/j.epsl.2009.10.021

Dufresne A, Wolken G, Hilbert C, Bessette-Kirton EK, Coe JA, Geertsema M, Ekstrom G (2019) The 2016 Lamplugh landslide: Alaska: deposit structures and emplacement dynamics. Landslides 16:2301-2319. https://doi.org/10.1007/s10346-019-01225-4

Duhart, P, Sepúlveda, V, Garrido, N, Mella, M, Quiroz, D, Fernández, J, Moreno, H, Hermosilla, G (2019) The Santa Lucia landslide disaster, Chaitén-Chile: origin and effects. In: Kean, JW, Coe, JA, Santi, PM, and Guillen, BK (eds) Debris-flow hazards mitigation: mechanics, monitoring, modeling, and assessment, Proceedings of the 7th International Conference on Debris Flow Hazards Mitigation, Golden, Colorado, Association of Environmental \& Engineering Geologists Special Publication 28, pp. 653-660. doi: https://doi.org/10.25676/11124/173159

Dunning, SA, Rosser, NJ, McColl, ST, Reznichenko, NV (2015) Rapid sequestration of rock avalanche deposits within glaciers. Nature Communications 6, article number 7964

Ekström G, Stark CP (2013) Simple scaling of catastrophic landslide dynamics. Science 339:1416-1419. https://doi.org/10.1126/science.1232887

Elliott JL, Larsen CF, Freymueller JT, Motyka RJ (2010) Tectonic block motion and glacial isostatic adjustment in Southeast Alaska and adjacent Canada constrained by GPS measurements. J Geophys Res 115:B09407. https://doi.org/10.1029/2009JB007139

Etzelmüller B, Farbrot H, Guðmundsson Á, Humlum 0, Tveito OE, Björnsson H (2007) The regional distribution of mountain permafrost in Iceland. Permafr Periglac Process 18:185-1999

Evans SG, Clague JJ (1994) Recent climatic change and catastrophic geomorphic processes in mountain environments. Geomorphology 10:107-128

Evans, SG, Clague, JJ (1999) Rock avalanches on glaciers in the Coast and St. Elias Mountains, British Columbia. In: Slope stability and landslides. Proceedings of the 13th Annual Geotechnical Society Symposium, Vancouver, B.C., pp 115-123. https:// www.researchgate.net/publication/283476315_Rock_avalanches_on_glaciers_in_the_ Coast and St Elias Mountains British Columbia

Evans SG, Bishop NF, Smoll LF, Murillo RV, Delancy KB, Oliver-Smith A (2009) A reexamination of the mechanism and human impact of catastrophic mass flows originating in Nevada Huascarán, Cordillera Blanca, Peru in 1092 and 1970. Eng Geol 108:96-118. https://doi.org/10.1016/j.enggeo.2009.06.020

Evans SG, Delaney KB (2015) Catastrophic mass flows in the mountain glacial environment. In: Haeberli W, Whiteman C, Shroder JF (eds) Snow and ice-related hazards, risks, and disasters. Elsevier, Amsterdam, pp 563-606. https://doi.org/10.1016/B9780-12-394849-6.00016-0

Faillettaz, J, Pralong, A, Funk, M, Deichmann, N (2008) Evidence of log-periodic oscillations and increasing icequake activity during the breaking-off of large ice masses. J Glaciol 54: 725-

Farinotti D, Immerzeel WW, de Kok RJ, Quincey DJ, Dehecq A (2020) Manifestations and mechanisms of the Karakoram glacier anomaly. Nat Geosci 13:8-16. https://doi.org/ 10.1038/s41561-019-0513-5

Fernandez, J, Coloma, F (2018) Informa Técnico Remoción en Masa, Ruta x-728, Rio Norte. SERNAGEOMIN INF-AYSEN-02.2018, $22 \mathrm{p}$

Fischer L, Kääb A, Huggel C, Noetzli J (2006) Geology, glacier retreat and permafrost degradation as controlling factors of slope instabilities in a high-mountain rock wall: the Monte Rosa east face. Nat Hazards Earth Syst Sci 6:761-772. https://doi.org/ 10.5194/nhess-6-761-2006

Fischer L, Purves RS, Huggel C, Noetzli J, Haeberli W (2012) On the influence of topographic, geological and cryospheric factors on rock avalanches and rock falls in high-mountain areas. Nat Hazards Earth Syst Sci 12:241-254. https://doi.org/10.5194/ nhess-12-241-2012 
Fischer L, Huggel C, Kääb A, Haeberli W (2013) Slope failures and erosion rates on a glacierized high-mountain face under climatic changes. Earth Surf Process Landf 38:836-846. https://doi.org/10.1002/esp.3355

Forsythe N, Fowler HJ, Li X, Blenkinsop S, Pritchard D (2017) Karakoram temperature and glacial melt driven by regional atmospheric circulation variability. Nat Clim Chang 7:664-673. https://doi.org/10.1038/NCLIMATE3361

Fox M, Herman F, Kissling E, Willett SD (2015) Rapid exhumation in the Western Alps driven by slab detachment and glacial erosion. Geology 43:379-382. https://doi.org/ 10.1130/G36411.1

Francis PW, Gardeweg M, Ramirez CF, Rothery DA (1985) Catastrophic debris avalanche deposit of Socompa volcano, northern Chile. Geology 13:600-603

Fraser JE, Searle MP, Parrish RR, Noble SR (2001) Chronology of deformation, metamorphism, and magmatism in the southern Karakoram Mountains. Geol Soc Am Bull 113:1443-1455

Friele P, Millard T, Mitchell A, Allstadt K, Menounos B, Geertsema M, Clague JJ (2020) Observations on the May 2019 Joffre Peak landslides, British Columbia. Landslides 17:913-930. https://doi.org/10.1007/s10346-019-01332-2

Gariano SL, Guzzetti F (2016) Landslides in a changing climate. Earth Sci Rev 162:227252. https://doi.org/10.1016/j.earscirev.2016.08.011

Geertsema, M (2012) Initial observations of the 11 June 2012 rock/ice avalanche, Lituya Mountain, Alaska. The First Meeting of Cold Region Landslides Network, Harbin China, 5 p. https://doi.org/10.13140/2.1.2473.5682

Geertsema M, Clague JJ, Schwab JW, Evans SG (2006) An overview of recent large catastrophic landslides in northern British Columbia, Canada. Eng Geol 83:120-143

Georgieva V, Melnick D, Schildgen TF, Ehlers TA, Lagabrielle Y, Enkelmann E, Strecker MR (2016) Tectonic control on rock uplift, exhumation, and topography above an oceanic ridge collision: Southern Patagonian Andes $\left(47^{\circ} \mathrm{S}\right)$, Chile. Tectonics 35:1317-1341. https://doi.org/10.1002/2016TC004120

Gischig VS, Moore JR, Evans KF, Amann F, Loew S (2011a) Thermomechanical forcing of deep rock slope deformation: 1. Conceptual study of a simplified slope. J Geophys Res 116:F04010. https://doi.org/10.1029/2011JF002006

Gischig VS, Moore JR, Evans KF, Amann F, Loew S (2011b) Thermomechanical forcing of deep rock slope deformation: 2 . The Randa rock slope instability. J Geophys Res 116:F04011. https://doi.org/10.1029/2011JF002007

Glasser NF, Holt, TO, Evans ZD, Davies BJ, Pelto M, Harrison S (2016) Recent spatial and temporal variations in debris cover on Patagonian glaciers. Geomorphology 273:202216. https://doi.org/10.1016/j.geomorph.2016.07.036

Glüer, F (2011) Investigation of rock slope failures triggered by the Aysén 2007 earthquake (Patagonia, Chile). Masters Thesis, TU Munich and ETH Zurich, $66 \mathrm{p}$

Grämiger LM, Moore JR, Gischig VS, Loew S (2018) Thermomechanical stresses drive damage of Alpine valley rock walls during repeat glacial cycles. J Geophys Res Earth Surf 123:2620-2646. https://doi.org/10.1029/2018JF004626

Gruber S, Hoelzle M, Haeberli W (2004) Permafrost thaw and destabilization of Alpine rock walls in the hot summer of 2003. Geophys Res Lett 31:L13504. https://doi.org/ 10.1029/2004GL020051

Gruber S, Haeberli W (2007) Permafrost in steep bedrock slopes and its temperaturerelated destabilization following climate change. J Geophys Res 112:F02S18. https:// doi.org/10.1029/2006JF000547

Gruber S (2012a) Derivation and analysis of a high resolution estimate of global permafrost zonation. Cryosphere 6:221-233. https://doi.org/10.5194/tc-6-221-2012

Gruber, S (2012b) Global permafrost zonation index map, http://www.geo.uzh.ch/ microsite/cryodata/pf_global/, last accessed July, 2017

Guthrie RH, Friele P, Allstadt K, Roberts N, Evans SG, Delaney KB, Roche D, Clague JJ, Jakob M (2012) The 6 August 2010 Mount Meager rock slide-debris flow, Coast Mountains, British Columbia: characteristics, dynamics, and implications for hazard and risk assessment. Nat Hazards Earth Syst Sci 12:1277-1294

Haeberli W, Beniston M (1998) Climate change and its impacts on glaciers and permafrost in the Alps. Ambio 27:258-265

Haeberli W, Kääb A, Paul F, Chiarle M, Mortara G, Mazza A, Deline P, Richardson S (2002) A surge-type movement at Ghiacciaio del Belvedere and a developing slope instability in the east face of Monte Rosa, Macugnaga, Italian Alps. Norsk Geografisk Tidsskrift Norwegian Journal of Geography 56:104-111. https://doi.org/10.1080/ 002919502760056422

Haeberli W, Huggel C, Kääb A, Oswald S, Polkvoj A, Zotikov I, Osokin N (2004) The KolkaKarmadon rock/ice slide of 20 September 2002 - an extraordinary event of historical dimensions in North Ossetia (Russian Caucasus). J Glaciol 50:533-546

Haeberli W, Schaub Y, Huggel C (2017) Increasing risks related to landslides from degrading permafrost into new lakes in de-glaciating mountain ranges. Geomorphology 293:405-417. https://doi.org/10.1016/.geomorph.2016.02.009
Harris C, Arenson LU, Christiansen HH, Etzelmüller B, Frauenfelder R, Gruber S, Haeberli W, Hauck C, Hölzle M, Humlum O, Isaksen K, Kääb A, Kern-Lütschg MA, Lehning M, Matsuoka N, Murton JB, Nötzli J, Phillips M, Ross N, Seppälä M, Springman SM, Mühll DV (2009) Permafrost and climate in Europe: monitoring and modeling thermal, geomorphological and geotechnical responses. Earth-Sci Rev 92:117-171. https:// doi.org/10.1016/j.earscirev.2008.12.002

Hasler A, Gruber S, Beutel J (2012) Kinematics of steep bedrock permafrost. J Geophys Res 117:F01016. https://doi.org/10.1029/2011JF001981

Hauser, A (2002) Rock avalanche and resulting debris flow in Estero Parraguirre and Río Colorado, Región Metropolitana, Chile. In: Evans, SG and DeGraff, JV, (eds) Catastrophic landslides: effects, occurrence, and mechanisms: Boulder, Colorado, Geological Society of America Reviews in Engineering Geology, v. XV, pp. 135-148

Helmstetter A, Garambois S (2010) Seismic monitoring of Sechilienne rockslide (French Alps): analysis of seismic signals and their correlation with rainfalls. J Geophys Res 115:F03016. https://doi.org/10.1029/2009JF001532

Hermanns RL, Valderrama P, Fauqué L, Penna IM, Sepúlveda S, Moreiras S, Zavala Carrión B (2012) Landslides in the Andes and the need to communicate on an interandean level on landslide mapping and research. Rev Asoc Geol Argent 69:321-327

Hewitt K (1988) Catastrophic landslides deposits in the Karakoram Himalaya. Science 242:64-67. https://doi.org/10.1126/science.242.4875.64

Hewitt K (2005) The Karakoram anomaly? Glacier expansion and the 'elevation effect,' Karakoram Himalaya. Mt Res Dev 25:332-340

Hewitt K (2009) Rock avalanches that travel onto glaciers and related developments, Karakoram Himalaya, Inner Asia. Geomorphology 103:66-79. https://doi.org/10.1016/ j.geomorph.2007.10.017

Hibert C, Mangeney A, Grandjean G, Baillard C, Rivet D, Shapiro NM, Satriano C, Maggi A, Boissier P, Ferranzzini V, Crawford W (2014) Automated identification, location, and volume estimation of rockfalls at Piton de la Fournaise volcano. J Geophys Res Earth Surf 119:1082-1105. https://doi.org/10.1002/2013JF002970

Hibert C, Michéa D, Provost F, Malet J-P, Geertsema M (2019) Exploration of continuous seismic recordings with a machine learning approach to document $20 \mathrm{yr}$ of landslide activity in Alaska. Geophys J Int 219:1138-1147. https://doi.org/10.1093/gji/ggz354

Higman, B., Shugar, DH, Stark, CP, Ekström, G, Koppes, MN, Lynett, P, Dufresne, A, Haeussler, PJ, Geertsema, M, Gulick, S, Mattox, A, Venditti, JG, Walton, MAL, McCall, N, Mckittrick, E, Maclnnes, B, Bilderback, EL, Tang, H, Willis, MJ, Richmond, B, Reece, RS, Larsen, C, Olson, B, Capra, J, Ayca, A, Bloom, C, Williams, H, Bonno, D, Weiss, R, Keen, A, Skanavis, V, Loso, M (2018) The 2015 landslide and tsunami in Taan Fiord, Alaska: Scientific Reports 8:12993. doi: https://doi.org/10.1038/s41598-018-30475-w

Hock, R, Rasul, G, Adler, C, Cáceres, B, Gruber, S, Hirabayashi, Y, Jackson, M, Kääb, A, Kang, S, Kutuzov, S, Milner, A, Molau, U, Morin, S, Orlove, B, Steltzer, H (2020) High mountain areas. In: IPCC special report on the ocean and cryosphere in a changing climate [H.-O. Pörtner, D.C. Roberts, V. Masson-Delmotte, P. Zhai, M. Tignor, E. Poloczanska, K. Mintenbeck, A. Alegría, M. Nicolai, A. Okem, J. Petzold, B. Rama, N.M. Weyer (eds)]. https://www.ipcc.ch/site/assets/uploads/sites/3/2019/11/ 06_SROCC_Ch02_FINAL.pdf

Hoelzle M, Chinn T, Stumm D, Paul F, Zemp M, Haeberli W (2007) The application of glacier inventory data for estimating past climate change effects on mountain glaciers: a comparison between the European Alps and the Southern Alps of New Zealand. Glob Planet Chang 56:69-82

Hovius N, Stark CP, Allen PA (1997) Sediment flux from a mountain belt derived by landslide mapping: Geology 25:231-234. doi: https://doi.org/10.1130/00917613(1997)025<0231:SFFAMB >2.3.C0;2

Huggel C, Zgraggen-Oswald S, Haeberli W, Kääb A, Polkvoj A, Galushkin I, Evans SG (2005) The 2002 rock/ice avalanche at Kolka/Karmadon, Russian Caucasus: assessment of extraordinary avalanche formation and mobility, and application of QuickBird satellite imagery. Nat Hazards Earth Syst Sci 5:173-187. https://doi.org/10.5194/ nhess-5-173-2005

Huggel, C, Gruber, S, Caplan-Auerbach, J, Wessels, RL, Molnia, BF (2008) The 2005 Mt. Steller, Alaska, rock-ice avalanche: a large slope failure in cold permafrost. In: 9th International Conference on Permafrost, Fairbanks, Alaska, 29 June 2008-3 July 2008, pp. 747-752

Huggel C, Clague JJ, Korup 0 (2012) Is climate change responsible for changing landslide activity in high mountains? Earth Surf Process Landf 37:77-91. https://doi.org/ 10.1002/esp.2223

Hürlimann M, Coviello V, Bel C, Guo Z, Berti M, Graf C, Hübl J, Miyata S, Smith JB, Yin H (2019) Debris-flow monitoring and warning: review and examples. Earth-Sci Rev 199:102981. https://doi.org/10.1016/j.earscirev.2019.102981

Huss M, Hock R (2015) A new model for global glacier change and sea-level rise. Front Earth Sci 3:1-22. https://doi.org/10.3389/feart.2015.00054 
IPCC (2013) Climate change 2013: the physical science basis. Contribution of working group I to the fifth assessment report of the Intergovernmental Panel on Climate Change. In: Stocker, T.F., Qin, D., Plattner, G-K, Tignor, M., Allen, SK, Boschung, J, Nauels, A, Xia, Y, Bex V, Midgley, PM (eds) Cambridge University Press, Cambridge, 1535 pp. https://www.ipcc.ch/report/ar5/wg1/

Iverson RM, George DL, Allstadt K, Reid MR, Collins BD, Vallance JW, Schilling SP, Godt JW, Cannon CM, Magirl CS, Baum RL, Coe JA, Schulz WH, Bower JB (2015) Landslide mobility and hazards: implications of the 2014 Oso disaster. Earth Planet Sci Lett 412:197-208. https://doi.org/10.1016/j.epsl.2014.12.020

Jacquemart M, Loso M (2019) Catastrophic glacier collapse and debris flow at Flat Creek. Alaska Park Science 18:16-25 https://www.nps.gov/articles/aps-18-1-3.htm

Jacquet J, McCoy SW, McGrath D, Nimick DA, Fahey M, O'Kuinghttons J, Friesen BA, Leidich J (2017) Hydrologic and geomorphic changes resulting from episodic glacial lake outburst floods: Rio Colonia, Patagonia, Chile. Geophys Res Lett 44:854-864. https://doi.org/10.1002/2016GL071374

Johnson AJ, Larsen CF, Murphy N, Arendt AA, Zirnheld SL (2013) Mass balance in the Glacier Bay area of Alaska, USA, and British Columbia, Canada, 1995-2011, using airborne laser altimetry. J Glaciol 59:632-648. https://doi.org/10.3189/2013JoG12101

Kääb A (2002) Monitoring high-mountain terrain deformation from repeated air and Spaceborne optical data: examples using digital aerial imagery and ASTER data. ISPRS J Photogramm Remote Sens 57:39-52. https://doi.org/10.1016/S09242716(02)00114-4

Kääb A, Berthier E, Nuth C, Gardelle J, Arnaud Y (2012) Contrasting patterns of early twenty-first-century glacier mass changed in the Himalayas. Nature 488:495-498. https://doi.org/10.1038/nature11324

Kanamori H, Given JW (1982) Analysis of long-period seismic waves excited by the May 18, 1980 eruption of Mount St. Helens - a terrestrial monopole? J Geophys Res 87:5422-5432

Khattak GA, Owen LA, Kamp U, Harp EL (2010) Evolution of earthquake-triggered landslides in the Kashmir Himalaya, northern Pakistan. Geomorphology 115:102108. https://doi.org/10.1016/j.geomorph.2009.09.035

Koons PO (1990) The two-sided orogen: collision and erosion from the sandbox to the Southern Alps, New Zealand. Geology 18:679-682

Korup 0, Seidemann J, Mohr CH (2019) Increased landslide activity on forested hillslopes following two recent volcanic eruptions in Chile. Nat Geosci 12:284-289. https:// doi.org/10.1038/s41561-019-0315-9

Kos A, Amann F, Strozzi T, Delaloye R, von Ruette J, Springman S (2016) Contemporary glacier retreat triggers a rapid landslide response, Great Aletsch Glacier, Switzerland. Geophys Res Lett 43:466-12,474. https://doi.org/10.1002/2016GL071708

Lacassin R, Tapponnier P, Bourjot L (1990) Culminations d'échelle crustale et imbrication de la lithosphe're dans les Alpes, apports du profil ECORS-CROP. C R Acad Sci Ser II 310:807-814

Larsen CF, Motyka RJ, Freymueller JT, Echelmeyer KA, Ivins ER (2005) Rapid viscoelastic uplift in Southeast Alaska caused by post-Little ice age glacial retreat. Earth Planet Sci Lett 237:548-560. https://doi.org/10.1016/j.epsl.2005.06.032

Leloup PH, Arnaud N, Sobel ER, Lacassin R (2005) Alpine thermal and structural evolution of the highest external crystalline massif: the Mont Blanc. Tectonics 24:TC4002. https://doi.org/10.1029/2004TC001676

Little TA, Cox S, Vry JK, Batt G (2005) Variations in exhumation level and uplift rate along the oblique-slip Alpine Fault, central Southern Alps, New Zealand. Geol Soc Am Bull 117:707-723. https://doi.org/10.1130/B25500.1

Magnin F, Josnin J-Y, Ravanel L, Pergaud J, Pohl B, Deline P (2017) Modelling rock wall permafrost degradation in the Mont Blanc massif from the LIA to the end of the 21st century. Cryosphere 11:1813-1834. https://doi.org/10.5194/tc-11-1813-2017

Mather AE, Hartley AJ, Griffiths JS (2014) The giant coastal landslides of northern Chile: tectonic and climate interactions on a classic convergent plate margin. Earth Planet Sci Lett 388:249-256. https://doi.org/10.1016/j.epsl.2013.10.019

McColl ST (2012) Paraglacial rock-slope stability. Geomorphology 153-154:1-16. https:// doi.org/10.1016/j.geomorph.2012.02.015

McSaveney, MJ (2002) Recent rockfalls and rock avalanches in Mount Cook National Park, New Zealand. In: Evans, SG, DeGraff, JV (eds) Catastrophic landslides: effects, occurrence, and mechanisms. Boulder, Colorado, Geological Society of America Reviews in Engineering Geology, v. XV, pp. 35-70

McSaveney, MJ, Downes, G (2002) Application of landslide seismology to some New Zealand rock avalanches. In: Rybar, J, Stemberk, J, and Wagner, P, (eds.). Landslides, Lisse, Balkema, p. 649-654

McSaveney MJ, Cox SC, Hancox GT (2014) Seeking a credible cause of the recent increase in rock-avalanche frequency in New Zealand's Southern Alps. Abstract. American Geophysical Union Fall Meeting, San Francisco, 15-19 December 2014

McSaveney MJ, Cox SC, Hancox GT (2015) Increasing rock-avalanche frequency correlates with increasing seismic moment release in New Zealand's Southern Alps. Geophys Res
Abstr 17:EGU2015-EGU8074 http://meetingorganizer.copernicus.org/EGU2015/ EGU2015-8074.pdf

Miller, DJ (1960) Giant waves in Lituya Bay Alaska. U.S. Geological Survey Professional Paper 354-C, US Geological Survey, Reston, Virginia, pp. 51-86, one 1:50,000 scale sheet. https://pubs.usgs.gov/pp/0354c/report.pdf

Mullan, AB, Stuart SJ, Hadfield, MG, Smith MJ (2010) Report on the review of NIWA's 'Seven-Station' temperature series. NIWA Information Series No. 78, ISSN 1174-264X, 175p. http://www.niwa.co.nz/our-science/climate/information-and-resources/nztemp-record/seven-station-series-temperature-data. [accessed Dec 13 2019]

Mullan AB (2012) Applying the Rhoades and Salinger method to New Zealand's "SevenStation" temperature series. Weather and Climate 32:24-38

Nadim F, Kjekstad 0, Peduzzi P, Herold C, Jaedicke C (2006) Global landslide and avalanche hotspots. Landslides 3:159-173. https://doi.org/10.1007/s10346-006-0036-1

Nair-Bedouelle S (2020) Foreward by Shamila-Nair Beouelle for the Journal of the International Consortium on Landslides. Landslides 17:1. https://doi.org/10.1007/ s10346-019-01328-y

Nakata, T (1989) Active faults of the Himalaya of India and Nepal: In: Malinconico, L.L., Lillie, R.J. (eds) Tectonics of the western Himalayas, Geological Society of America Special Paper 232, pp. 242-264

NOAA (2017) United States National Climate Report - annual 2016. https:// www.Ncdc.Noaa.Gov/sotc/national/201613 last accessed November 2019

Nocquet JC, Sue C, Walpersdorf A, Tran T, Lenôtre N, Vernant P, Cushing M, Jouanne F, Masson F, Baize S, Chéry J, van der Beek PA (2016) Present day uplift of the Western Alps. Scientific Reports 6:28404. https://doi.org/10.1038/srep28404

Oki T (2019) Foreward by Prof. Taikan OKI of the United Nations University (UNU) for the Journal of the International Consortium on Landslides. Landslides 16:2299-2300. https://doi.org/10.1007/s10346-019-01302-8

Oppikofer T, Hermanns RL, Redfield TR, Sepúlveda SA, Duhart P, Bascuán I (2012) Morphologic description of the Punta Cola rock avalanche and associated minor rockslides caused by the 21 April 2007 Aysén earthquake (Patagonia, southern Chile). Rev Asoc Geol Argent 69:339-353

Pastick NJ, Jorgenson MT, Wylie BK, Nield SJ, Johnson KD, Finley AO (2015) Distribution of near-surface permafrost in Alaska: estimates of present and future conditions. Remote Sens Environ 168:301-315. https://doi.org/10.1016/j.rse.2015.07.019

Paul F, Kääb A, Maisch M, Kellenberger T, Haeberli W (2004) Rapid disintegration of Alpine glaciers observed with satellite data. Geophys Res Lett 31:L21402

Paul, F (2020) A 60-year chronology of glacier surges in the central Karakoram from the analysis of satellite image time-series: Geomorphology 352: 106993. doi: https:// doi.org/10.1016/j.geomorph.2019.106993

Pelto, M (2015) North Leones Glacier retreat and new landslide, Patagonia, Chile. AGU Blog posting on March 26, 2015. https://blogs.agu.org/fromaglaciersperspective/ 2015/03/26/north-leones-glacier-retreat-and-new-landslide-patagonia-chile/

Petley DN (2010) On the impact of climate change and population growth on the occurrence of fatal land-slides in South, East and SE Asia. Q J Eng Geol Hydrogeol 43:487-496. https://doi.org/10.1144/1470-9236/09-001

Petley, DN (2012) The Siachen Glacier avalanche (138 people killed) was an ice-rock avalanche. AGU Landslide Blog 12 April 2012 https://blogs.agu.org/landslideblog/ 2012/04/12/the-siachen-glacier-avalanche-135-people-killed-was-actually-alandslide/

Pflaker G, Hudson T, Bruns T, Rubin M (1978) Late Quaternary offsets along the Fairweather Fault and crustal plate interactions in southern Alaska. Can J Earth Sci 15:805-816. https://doi.org/10.1139/e78-085

Post, A (1967) Effects of the March 1964 Alaska earthquake on glaciers. U.S. Geological Survey Professional Paper 544-D, U.S. Geological Survey, Reston, Virginia, 42 p. https://pubs.usgs.gov/pp/0544d/

Ravanel L, Allignol F, Deline P, Gruber S, Ravello M (2010) Rock falls in the Mont Blanc massif in 2007 and 2008. Landslides 7:493-501. https://doi.org/10.1007/s10346-010-0206-z

Ravanel L, Deline P (2011) Climate influence on rockfalls in high-Alpine steep rockwalls: the north side of the Aiguilles de Chamonix (Mont Blanc massif) since the end of the 'Little Ice Age'. Holocene 21:357-365. https://doi.org/10.1177/0959683610374887

Rebetez M, Reinhard M (2008) Monthly air temperature trends in Switzerland 1901-2000 and 1975-2004. Theor Appl Climatol 91:27-34. https://doi.org/10.1007/s00704-007-0296-2

Ringot E, Rivera A, Casassa G (2003) Contribution of the Patagonia Icefields of South America to sea level rise. Science 302:434-437. https://doi.org/10.1126/ science.1087393

Saemundsson P, Morino C, Helgason JK, Conway SJ, Pétursson HG (2018) The triggering factors of the Móafellshyrna debris slide in northern Iceland: intense precipitation, earthquake activity and thawing of mountain permafrost. Sci Total Environ 621:11631175. https://doi.org/10.1016/j.scitotenv.2017.10.111 
Salinger JM, Basher RE, Fitzharris B, Hay JE, Jones PD, MacVeigh JP, Schmidely-Leleu (1995) Climate trends in the South-West Pacific. Int J Climatol 15:285-302

Salzmann, N, Machguth, H, Linsbauer, A (2012) The Swiss alpine glaciers' response to the global ' $2{ }^{\circ} \mathrm{C}$ air temperature target. Environ Res Lett 7: 044001,12 p. doi: https:// doi.org/10.1088/1748-9326/7/4/04400S

Sassa K (2019a) Registered speakers of the fifth world landslide forum-implementing and monitoring the Sendai landslide partnerships 2015-2025-voluntary contribution to the Sendai framework 2015-2030 and the agenda 2030-sustainable development goals. Landslides 16:1423-1424. https://doi.org/10.1007/s10346-019-01213-8

Sassa K (2019b) The Kyoto Landslide Commitment 2020: first signatories. Landslides 16:2053-2057. https://doi.org/10.1007/s10346-019-01295-4

Schindler C, Cuenod Y, Eisenlohr T, Joris C-L (1993) Die Ereignisse vom 18. April und 9. Mai 1991 bei Randa (VS) - ein atypischer Bergsturz in Raten. Eclogae Geol Helv 86:643-665

Schlögel R, Torgoev I, De Marneffe C, Havenith H (2011) Evidence of a changing sizefrequency distribution of landslides in the Kygyz Tien Shan, Central Asia. Earth Surf Process Landf 36:1658-1669. https://doi.org/10.1002/esp.2184

Schneider, JF, Gruber, FE, Mergili, M (2013) Impact of large landslides, mitigation measures. Sapeinza Universitá Editrice, Padova, pp. 73-84. doi: https://doi.org/ 10.4408/JEGE.2013-06.B-06

Searle MP (1991) Geology and tectonics of the Karakoram Mountains. John Wiley and Sons Ltd, Chichester, $358 \mathrm{p}$

Searle MP, Phillips RJ (2007) Relationships between right-lateral shear along the Karakoram fault and metamorphism, magmatism, exhumation and uplift: evidence from the K2-Gasherbrum-Pangong ranges, North Pakistan and Ladakh. J Geol Soc 164:439-450. https://doi.org/10.1144/0016-76492006-072

Searle, MP, Parrish, RP, Thow, AV, Noble, SR, Phillips, RJ, Waters, DJ (2010) Anatomy, age and evolution of a collisional mountain belt: the Baltoro granite batholith and Karakoram metamorphic complex, Pakistani Karakoram. J Geol Soc, London, pp. 183-202. doi: https://doi.org/10.1144/0016-76492009-043

Sepúlveda SA, Serey A, Lara M, Pavez A, Robolledo S (2010) Landslides induced by the April 2007 Aysén Fjord earthquake, Chilean Patagonia. Landslides 7:483-492. https:// doi.org/10.1007/s10346-010-0203-2

Serey A, Piñero-Feliciangeli L, Sepúlveda S, Poblete F, Petley DN, Murphy W (2019) Landslides induced by the 2010 Chile megathrust earthquake: a comprehensive inventory and correlations with geological and seismic factors. Landslides 16:11531165. https://doi.org/10.1007/s10346-019-01150-6

SERNAGEOMIN (2003) Mapa Geológico de Chile: versión digital, escala 1:1:1,000,000. Servico Nacional de Geología y Minería, Santiago, Chile

SERNAGEOMIN (2018) Excepcional volcãnica MEV No. 001/2018, Cordón Mariano Moreno, Campos de Hielo Sur, Parque Nacional Bernardo O'Higgins. $6 \mathrm{p}$

Sidle RC, Burt TP (2009) Temperate forests and rangelands. In: Slaymaker 0, Spencer T, Embleton-Hamann C (eds) Geomorphology and global environmental change. Cambridge University Press, Cambridge, pp 321-343

Slaymaker $O$ (1990) Climate change and erosion processes in mountain regions of western Canada. Mt Res Dev 10:171-182

Svennevig K, Solgaard AM, Salehi S, Dahl-Jensen T, Boncori M, JP LTB, Voss PH (2019) A multidisciplinary approach to landslide monitoring in the Arctic: case study of the March 2018 ML 1.9 seismic event near the Karrat 2017 landslide. Geological Survey of Denmark and Greenland Bulletin 43:e2019430208. https://doi.org/10.34194/GEUSB-201943-02-08

Taylor M, Yin A (2009) Active structures of the Himalyan-Tibetan orogen and their relationships to earthquake distribution, contemporary strain field, and Cenozoic volcanism. Geosphere 5:199-214. https://doi.org/10.1130/GES00217.1

Thomson AM, Calvin KV, Smith SJ, Kyle GP, Volke A, Patel P, Delgado-Arias S, BondLamberty B, Wise MA, Clarke LE, Edmonds JA (2011) RCP4.5: a pathway for stabilization of radiative forcing by 2100. Clim Chang 109:77-94. https://doi.org/ 10.1007/s10584-011-0151-4

USGCRP (2018) Impacts, risks, and adaptation in the United States: fourth National Climate Assessment, volume II. In: Reidmiller, DR, Avery, CW, Easterling, DR, Kunkel, KE, Lewis, KLM, Maycock, TK, Stewart, BC (eds) U.S. Global Change Research Program, Washington, DC, USA, 1515 pp. doi: https://doi.org/10.7930/NCA4.2018

van Oldenborgh, GJ, Collins, M, Arblaster, J, Christensen, JH, Marotzke, J, Power, SB, Rummukainen, M, Zhou, T (2013) Annex I: Atlas of global and regional climate projections. In: Stocker, TF, Qin, D, Plattner, G-K, Tignor, M, Allen, SK, Boschung, J, Nauels, A, Xia, Y, Bex, V, Midgley, PM, (eds), Climate Change 2013: the physical science basis. Contribution of Working Group I to the Fifth Assessment Report of the Intergovernmental Panel on Climate Change. Cambridge University Press, Cambridge, pp. 1311-1393. https://www.ipcc.ch/pdf/assessment-report/ar5/wg1/ WG1AR5_Annexl_FINAL.pdf
Wallis D, Carter A, Phillips RJ, Parsons AJ, Searle MP (2016) Spatial variation in exhumation rates across Ladakh and the Karakoram: new apatite fission track data from the eastern Karakoram, NW India. Tectonics 35:704-721. https://doi.org/ 10.1002/2015TC003943

Walsh, J, Wuebbles, D, Hayhoe, K, Kossin, K, Kunkel, K, Stephens, G, Thorne, P, Vose, R, Wehner, M, Willis, J, Anderson, D, Doney, S, Feely, R, Hennon, P, Kharin, V, Knutson, T, Landerer, F, Lenton, T, Kennedy, J, Somerville, R (2014) Chapter 2: Our changing climate. In: Melillo, JM, Richmond, TC, Yohe GW, (eds), Climate change impacts in the United States: the third national climate assessment, U.S. Global Change Research Program. pp. 19-67. http://nca2014.globalchange.gov/report

Walsh JE, Bieniek PA, Brettschneider B, Euskirchen ES, Lader R, Thoman RL (2017) The exceptionally warm winter of 2015/16 in Alaska. J Clim 30:2069-2088. https:// doi.org/10.1175/JCLI-D-16-0473.1

Walter F, Deichmann N, Funk M (2008) Basal icequakes during changing subglacial water pressures beneath Gornergletscher, Switzerland. J Glaciol 54:511-521

Waqas A, Athar H (2019) Recent decadal variability of daily observed temperatures in Hindukush, Karakoram and Himalaya region in northern Pakistan. Clim Dyn 52:69316951. https://doi.org/10.1007/s00382-018-4557-9

Wasowski J, Lamanna C, Casarano D (2010) Influence of land-use change and precipitation patterns on landslide activity in the Daunia Apennines, Italy. Q J Eng Geol Hydrogeol 43:387-401

Weber S, Beutel J, Faillettaz J, Hasler A, Krautblatter M, Vieli A (2017) Quantifying irreversible movement in steep, fractured bedrock permafrost on Matterhorn (CH). Cryosphere 11:567-583. https://doi.org/10.5194/tc-11-567-2017

Weber S, Beutel J, Da Forno R, Geiger A, Gruber S, Gsell T, Hasler A, Keller M, Lim R, Limpach P, Meyer M, Talzi I, Thiele L, Tschudin C, Vieli A, Vonder Mühll D, Yücel M (2019) A decade of detailed observations (2008-2018) in steep bedrock permafrost at the Matterhorn Hörnligrat (Zermatt, CH). Earth Syst Sci Data 11:1203-1237. https:// doi.org/10.5194/essd-11-1203-2019

Whitehouse IE, Griffiths GA (1983) Frequency and hazard of large rock avalanches in the central Southern Alps, New Zealand. Geology 11:331-334

Willis MJ, Melkonian AK, Pritchard ME, Ramage JM (2012) Ice loss rates at the Northern Patagonian Icefield derived using a decade of satellite remote sensing. Remote Sens Environ 117:184-198

Wilson, FH, Hults, CP, Mull, CG, Karl, SM (2015) Geologic map of Alaska: U.S. Geological Survey Scientific Investigations Map 3340, U.S. Geological Survey, Reston, Virginia, 197 p., 2 sheets, scale 1:584,000, https://doi.org/10.3133/sim3340

Wilson R, Glasser NF, Reynolds JM, Harrison S, Anacona PI, Schaefer M, Shannon S (2018) Glacial lakes of the central and Patagonian Andes. Glob Planet Chang 162:275-291

Wood JL, Harrison S, Reinhardt L (2015) Landslide inventories for climate impacts research in the European Alps. Geomorphology 228:398-408. https://doi.org/ 10.1016/j.geomorph.2014.09.005

Wuebbles DJ, Kunkel K, Wehner M, Zobel Z (2014) Severe weather in United States under a changing climate. EOS, Transactions, American Geophysical Union 95:149-150. https://doi.org/10.1002/2014E0180001

Yamada M, Matsuchi Y, Chigira M, Mori J (2012) Seismic recordings of landslides caused by Typhoon Talas (2011), Japan. Geophys Res Lett 39:L13301

Zekollari H, Huss M, Farinotti D (2019) Modelling the future evolution of glaciers in the European Alps under the EURO-CORDEX RCM ensemble. Cryosphere 13:1125-1146. https://doi.org/10.5194/tc-13-1125-2019

Zemp M, Haeberli W, Hoelzle M, Paul F (2006) Alpine glaciers to disappear within decades. Geophysical Research Letters 33:L13504. https://doi.org/10.1029/ 2006GL026319

Zemp M, Huss M, Thibert E, Eckert N, McNabb R, Huber J, Barandun M, Machguth H, Nussbaumer SU, Gärtner-Roer I, Thomson L, Paul F, Maussion F, Kutuzov S, Cogley JG (2019) Global glacier mass changes and their contributions to sea-level rise from 1961 to 2016.https://www.ncbi.nlm.nih.gov/pubmed/30962533 Nature 568(7752):382386. https://doi.org/10.1038/s41586-019-1071-0

\section{J. A. Coe (D.}

U. S. Geological Survey,

Denver Federal Center,

MS 966, Denver, C0 80225, USA

Email: jcoe@usgs.gov 